Finance and Economics Discussion Series Divisions of Research \& Statistics and Monetary Affairs Federal Reserve Board, Washington, D.C.

\title{
Post Brown vs. the Board of Education: The Effects of the End of Court-Ordered Desegregation
}

Byron F. Lutz

2005-64

NOTE: Staff working papers in the Finance and Economics Discussion Series (FEDS) are preliminary materials circulated to stimulate discussion and critical comment. The analysis and conclusions set forth are those of the authors and do not indicate concurrence by other members of the research staff or the Board of Governors.

References in publications to the Finance and Economics Discussion Series (other than acknowledgement) should be cleared with the author(s) to protect the tentative character of these papers. 


\title{
Post Brown vs. the Board of Education: The Effects of the End of Court-Ordered Desegregation
}

\author{
Byron F. Lutz* \\ Federal Reserve Board
}

December 19, 2005

\begin{abstract}
In the early 1990s, nearly forty years after Brown v. the Board of Education, three Supreme Court decisions dramatically altered the legal environment for court-ordered desegregation. Lower courts have released numerous school districts from their desegregation plans as a result. Over the same period racial segregation increased in public schools across the country a phenomenon which has been termed resegregation. Using a unique dataset, this paper finds that dismissal of a court-ordered desegregation plan results in a gradual, moderate increase in racial segregation and an increase in black dropout rates and black private school attendance. The increased dropout rates and private school attendance are experienced only by districts located outside of the South Census region. There is no evidence of an effect on white student dropout rates or private school attendance rates.
\end{abstract}

${ }^{*}$ Federal Reserve Board, Research Division, 20th \& C Sts., NW, Stop \#66, Washington DC 20551-0001; Byron.F.Lutz@frb.gov. This research was completed as part of the author's Ph.D. dissertation and was supported by a grant from the American Educational Research Association and by the National Science Foundation. The views expressed are those of the author and not necessarily those of the Federal Reserve Board or its staff. I owe thanks to several individuals for assistance with the data used in the paper. Daniel Feenberg generated the private school iterations of the NBER format 1990 School District Databook. Jacinta Ma of the Harvard Civil Rights Project provided and assisted with the date of desegregation order dismissal data. Christine Rossell and David Armor generously allowed me to use their survey data. Margo Schlanger provided the methodology used for the electronic legal searches. I thank Nirupama Rao for excellent research assistance. I thank the following individuals for useful comments and suggestions: Daron Acemoglu, Jon Gruber, Jon Guryan, Chris Hansen, Bill Kerr, Ashley Lester, Nancy Qian, Sarah Reber, Dan Sichel, John Yun and participants in the MIT Labor and Public Finance Lunches, the Spring 2005 NBER Children's Program Meeting and the University of Chiacgo GSB Applied Economics Workshop. I would particularly like to thank Josh Angrist, David Autor and Michael Greenstone. 


\section{Introduction}

Court-ordered desegregation was one of the most ambitious and controversial government policies of the last fifty years. Beginning in 1954 with the Brown v. Board of Education decision, the majority of the nation's large school districts were subject to mandatory desegregation plans. The plans produced dramatic increases in racial integration in the short-run. The long-run integrative effects varied from district to district. In some districts, long-run integration was achieved. In other districts the response of whites to the plans, often referred to as "white flight", undermined the plans' ability to achieve stable integration (Rossell and Armor 1996; Reber 2002; Welch and Light 1987). There is strong evidence that the plans reduced black dropout rates (Guryan 2004).

The number of new court-ordered desegregation plans peaked in the early 1970s and declined steadily thereafter. The Supreme Court, having been largely silent on the issue of desegregation during the 1980s, issued three decisions in the early 1990s which significantly altered the legal basis for court-ordered desegregation. It became easier to terminate court-mandated plans and the return of school control to local authority became the stated goal of all desegregation cases. These decisions signaled the end of the era of court-ordered desegregation: a large and possibly accelerating number of school districts have had their desegregation plans dismissed in the post-1990 period.

Racial segregation increased in public schools over the same period - a development which has been termed resegregation (Orfield and Eaton 1996; Boger 2002; Frankenberg, Lee and Orfield 2003; for a dissenting view, see Armor and Rossell 2002). Numerous observers have assumed an explicit link between the dismissal of desegregation plans and increasing segregation in public schools. A recent New York Times editorial states that "much of the blame [for resegregation] goes to the courts' increased hostility to desegregation suits" (New York Times 2003). Many scholarly articles have made similar assumptions (e.g. Boger 2002 pg. 3; Cherminsky 2002 pg. 5; Orfield 2001 pg. $15-16)$.

The effect of the end of court-ordered desegregation, however, is unclear. The dismissal of a desegregation plan does not necessarily result in increased segregation. Most plans have been in place for many years and there is evidence that a plan's ability to achieve integration erodes over time (Reber 2002). It is unclear whether or not desegregation plans are still imposing a constraint on racial segregation in the post-1990 period. If they are not imposing a constraint, segregation will not increase when a plan is dismissed.

Furthermore, even if the termination of a plan causes an increase in segregation, the termination may or may not have adverse welfare consequences for black students. The phase-out of the plans is occurring in a very different environment than that in which they were implemented. 
Residential segregation has decreased significantly (Glaeser and Vigdor 2002) and funding is much more equalized across schools (Card and Payne 1998; Murray, Evans and Schwab 1998; Hoxby 2001). Given the different environment, it is not clear that the dismissal of the plans will reverse the gains achieved by their implementation.

This paper examines the two questions raised above. First, does dismissal of a desegregation plan result in an increase in segregation? Second, what are the welfare implications of the end of court-ordered desegregation?

The first question is answered by providing estimates of the causal link between the dismissal of court-ordered desegregation plans and changes in racial segregation in public schools. Segregation is of interest because racial integration was the primary aim of court-ordered desegregation. Examining segregation levels provides evidence on the efficacy of what has been called the most ambitious and idealistic social experiment in U.S. history (Merelman 2002).

Segregation is also of interest because of a possible link with educational outcomes. There are numerous reasons why segregation levels may affect educational outcomes. Peer effects potentially play an important role in human capital production (Boozer, Krueger and Wolkon, 1992; Hoxby 2000; Angrist and Lang 2004; Hanushek, Kain and Rivkin 2002). The degree of segregation also likely influences the distribution and level of educational resources provided to minority students a point expressed memorably in the Brown decision's premise that separate schools are inherently unequal.

The second question this paper examines, what are the welfare implications of the end of courtordered desegregation, is addressed by estimating the causal link between dismissal and dropout rates and rates of private school attendance. A dismissal potentially causes a complex transformation of the school environment. The peer group a student experiences may change. In some cases long-distance bus rides are replaced by neighborhood school attendance. School districts under a court-ordered desegregation plan are monitored by the courts in regard to minority student performance. Dismissal of a desegregation plan returns a district to local control, removes the external monitoring and may therefore reduce the effort and resources expended on minority students. Finally, there is anecdotal evidence that dismissed school districts often engage in capital investment in minority neighborhoods (NAACP 2000; Goldring and Smrekar 2002).

These changes alter both the value and cost of education provided in a dismissed district. For example, the elimination of busing may reduce the costs associated with attendance, while a change in the peer group may increase or decrease the expected return to attendance. If the net value of the educational services provided by a school district is decreased by dismissal, there is an expectation that students previously on the margin for exiting the school district (i.e. those for 
whom the benefits of attendance were only marginally greater than the costs of attendance) will exit after dismissal. Dropout rates and rates of private school attendance rates for both black and white students are therefore examined in order to assess the net impact of the changes induced by the end of court-ordered desegregation.

My analysis uses a unique dataset, compiled from multiple sources, and an identification strategy based on the idiosyncratic timing of desegregation plan dismissals. The results suggest that dismissal induces a gradual increase in segregation levels. The magnitude of the increase is moderate. It is significantly smaller than the decrease in segregation that was achieved by the plans implementation. It should be noted, however, that the estimates reflect short-run effects. The long-run effects may be larger. In independent contemporaneous work, Clotfelter, Ladd and Vigdor (2005) also explore the connection between the dismissal of court-ordered desegregation plans and racial segregation and find that post-1993 dismissals result in an increase in racial segregation - a finding broadly consistent with the results of this paper. ${ }^{1}$

The increase in segregation documented in this paper does not necessarily reduce black welfare. The dropout and private school attendance results suggest, however, that the end of court-ordered desegregation does have negative welfare consequences for black students. Black dropout rates and black rates of private school attendance both increase in response to the dismissal of a desegregation plan. Viewed individually, these results might be ambiguous in regards to the welfare impact of dismissal. Viewed jointly, they strongly suggest the value of the educational services provided to black students decreases when a district is dismissed. The decrease in value reduces the welfare of black students and families residing in a dismissed district. These negative welfare consequences are confined to non-southern districts. The estimates are precise enough to rule out any sizeable effect on black student attendance patterns in the south.

Dismissal has no apparent impact on white dropout rates or white private school attendance rates. There is limited evidence, however, that the demographic profile of whites in a dismissed

\footnotetext{
${ }^{1}$ There are many differences in approach between this paper and Clotfelter, Ladd and Vigdor (2005) (henceforth CLV). Three of the more significant differences are as follows. First, CLV use a sample of the largest southern school districts. This paper uses a national sample restricted to those districts under court-order in 1991 . The different samples provide different counterfactuals for those districts dismissed within the sample period. CLV uses all large southern districts not dismissed in the sample period to provide a counterfactual (including districts never under court-order and those dismissed before the sample period), while this paper uses districts which remained under court-order as the counterfactual. As discussed below, the approach used in this paper appears justified based on observable school district characteristics. Second, this paper examines several outcome measures in addition to racial segregation such as dropout rates and rates of private school attendance by race. Examining these outcomes provides insight into the welfare implications of the end of court-ordered desegregation. Finally, this paper allows for more flexibility in the time pattern of effects of dismissal of a desegregation plan. This flexibility (in particular the estimation of a vector of coefficients for the period prior to dismissal - see below), as well as a set of rigorous robustness checks, is useful in assessing whether or not the estimated increase in segregation reflects the causal impact of dismissal.
} 
district changes - the education level of white mothers is higher and there is a lower probability of a white child being beneath the poverty line.

The paper proceeds as follows. Section 2 provides background information. Section 3 discusses the data. Section 4 presents the empirical model and results for the segregation outcome variables. Section 5 presents the empirical model and results for the dropout and private school enrollment outcome variables. Section 6 provides interpretation.

\section{Background Information}

\subsection{Court-Ordered Desegregation}

Although Brown v. Board of Education was issued in 1954, widespread desegregation did not begin until the Civil Rights Act of 1964, which banned racial discrimination in schools receiving federal aid. The 1968 Green decision (Green v. County School Board of New Kent County, 391 U.S. 430), which stipulated that school desegregation must begin immediately, further accelerated the process. Numerous southern districts were placed under court-ordered desegregation plans, many with mandatory busing components, and southern schools ultimately became the least segregated in the country.

The Keyes decision (Keyes v. Denver School District, 413 U.S. 189), issued in 1973, ruled that court-ordered desegregation could proceed in areas which had not practiced du jure segregation. Desegregation became viable in areas outside of the south and numerous northern and western school districts were placed under mandatory desegregation plans.

The Supreme Court issued no significant decisions relating to school desegregation between the mid-1970s and 1990. The flow of new desegregation orders from lower courts increased through the early 1970s and declined gradually thereafter. By 1990, the flow of new orders had virtually stopped. There has been only a single federal desegregation order that involved a mandatory student assignment plan since 1990 (Raffel 2002).

The legal environment for court-ordered desegregation changed radically with the 1991 Board of Education of Oklahoma City v. Dowell ruling (498 U.S. 237). This decision defines the requirements for a school district to be declared unitary - a term indicating a district is no longer operating an illegal, racially dual school system - and stipulates that once a district achieves unitary status it must be permanently released from court control. Even immediate and complete resegregation is acceptable, as long as the school district does not state its attendance policies are aimed at achieving racial segregation. Prior to the decision, it had been widely presumed that districts released from court control had an obligation to maintain a desegregated district (Orfield 2001; 
Lindseth 2002).

The Freeman v. Pitts decision (503 U.S. 467), issued in 1992, eases the burden placed on defendant school districts in desegregation suits. Finally, Missouri v. Jenkins (515 U.S. 70, 1995) limits enforcement options available to federal courts and states that restoration of school control to locally elected officials should be the primary goal of all desegregation cases.

These decisions collectively express the opinion that the courts have "done enough" in the area of school desegregation and that long-running desegregation cases should be moved to closure (Tushnet 1996). A large number of school districts have been released from their desegregation plans as a result of the above decisions and there is an apparent acceleration in the rate of dismissals. Most observers have concluded that the era of court-ordered desegregation is drawing to a close (Frankenburg, Lee and Orfield 2003, pg.20; Lindseth 2002, pg. 42). See Appendix A for additional information on court-ordered desegregation.

\subsection{The Dismissal Process}

The causal impact of desegregation plan dismissal on racial segregation and other outcome variables is identified in this paper from both whether a district is dismissed and when it is dismissed. It is therefore important to examine the process of dismissal in detail.

The process of dismissal, once initiated in the courts, typically takes several years. Once initiated, virtually all districts are subsequently dismissed from court supervision. Every contested motion for unitary status post-1990 has resulted in a dismissal. ${ }^{2}$

A dismissal can be initiated by any one of a number of agents, including defendant school districts, plaintiffs, federal district court judges and third parties such as parents of students in affected districts and non-school governmental bodies. The variety and idiosyncrasy of who initiates the dismissal process makes it unlikely that dismissal is a function of school district or community characteristics and preferences.

A few examples illustrate this point. Pinellas County, Florida, which serves St. Petersburg, had operated under a successful desegregation plan (success being defined as achieving high, long-term levels of black-white exposure). The defendant school board moved for dismissal (NAACP 2000). Cleveland, Ohio, which had one of the least successful court-ordered desegregation plans, is another example of a defendant school board moving for dismissal (179 F.3d 453, 6th Cir, 1999).

Charlotte, North Carolina is often cited as an example of successful court-ordered desegregation. The dismissal process in Charlotte began when a white parent filed suit against the district's race-

\footnotetext{
${ }^{2}$ NAACP 2000. Note that although Hillsborough County, Florida is cited as an exception to this trend, its desegregation plan was dismissed after the publication of NAACP 2000.
} 
based magnet school admission policy. A district court judge consolidated the magnet school case with the much older desegregation case. The district's desegregation plan was ultimately dismissed as a result (57 F.Supp.2d 228). Prince George's County, Maryland, a district where "white flight" undermined the ability of its desegregation plan to achieve stable integration, is another example of a third party initiating a dismissal. Over the objection of the school board, the county government, which was a major funding source for the school district, moved that the desegregation order be terminated (Lindseth 2002).

Finally, in many cases, district judges have chosen to clear their dockets of desegregation cases at their own initiative. For example, the judges in the Middle District of Alabama chose to begin active proceedings for all desegregation cases on their dockets (Parker 2000) - a decision which led to seven districts being dismissed in 2002 alone.

Once the process of dismissal begins, there is an element of randomness in the length of time it takes for a district to be dismissed. Decisions are often appealed, adding further randomness to the date of actual dismissal. A particularly striking example of the idiosyncratic nature of the timing involves Cleveland. The judge who had overseen the desegregation suit since its inception in 1973 passed away. His successor rapidly moved the case to termination.

A final relevant piece of legal background involves desegregation plans operated by districts not under court-order. Recent federal and Supreme Court rulings have made it more difficult to legally operate voluntary, non-court-ordered plans. ${ }^{3}$ Numerous school districts have terminated voluntary desegregation efforts as a result. Boston is a prominent example.

The trend toward the elimination of voluntary plans has two implications for this paper. First, school districts released from court-ordered plans have limited ability to maintain desegregation efforts (Lindseth 2002). Most dismissed districts have returned to some form of neighborhood schooling. In some cases, though, portions of the court-ordered desegregation plan have been maintained. Magnet school programs, in particular, are often retained after dismissal (Orfield and Lee 2004). Second, the trend away from voluntary desegregation plans potentially complicates the econometric identification of the effect of court-ordered desegregation plan dismissal (this point is discussed in greater detail in section 4).

\footnotetext{
${ }^{3}$ Among the more significant decisions are the following: Tuttle v. Arlington County School Bd, 195 F.3d 698 (4th Cir. 1999); Wessman v. Gittens, 160 F.3d 790 (1st Cir.); Adarand Constructors v. Pena, 515 U.S. $200 ;$ City of Richmond V. J.A. Croson Co., 488 U.S. 469.
} 


\section{Data}

This paper analyzes a nationally representative sample of school districts. The primary source of school district data is the Common Core of Data (CCD) produced by the National Center for Education Statistics. It contains basic descriptive data for the universe of public schools in the U.S. from 1987 to 2002. The School District Databook (SDDB), a school district-level tabulation of the U.S. Census, complements the CCD. It provides detailed demographic and housing data for the geographic areas served by school districts, but is only available for 1990 and 2000 .

No accurate national statistics are available concerning the number of court-ordered desegregation plans in place or the number of dismissals of such plans. Multiple sources are therefore used to generate two variables related to court-ordered desegregation - the presence of a court-ordered plan in 1991 and the dates of dismissal of these plans.

The primary source for the presence of a court-ordered plan is a 1991 nationally representative survey of school districts conducted by Christine Rossell and David Armor (Steel, Levine, Rossell and Armor 1993; Steel and Levine 1994). The survey contains detailed information on school desegregation programs. Both the content of the survey and its timing are ideally suited for the estimation strategy pursued in this paper.

The primary source of information on dismissal of desegregation orders is an unpublished table produced by the Harvard Civil Rights Project (Ma 2002). To supplement both this table, which does not claim to be comprehensive, and the Rossell and Armor survey data, I use several other sources. These include electronic searches on the legal search engines Courtlink and Pacer ${ }^{4}$, an unpublished list of school districts subject to desegregation suits to which the U.S. is a party maintained by the Civil Rights Division of the Justice Department, published and unpublished legal opinions obtained via LexisNexis and Westlaw, appendix C of Welch and Light (1987), a variety of media and internet sources (in particular the electronic archives of Education Week), school district documents such as budgets and minutes of school board meetings and, finally, private communications with school district officials.

Two panel datasets, organized at the school district-year level, are constructed from the above sources. $^{5}$ The first panel spans the 1987 - 2002 period and uses outcome variables constructed from the CCD. The second panel contains two periods, 1990 and 2000, and uses outcome variables

\footnotetext{
${ }^{4}$ Courtlink allows for electronic searches of Federal District Court dockets and Pacer provides electronic retrieval of these dockets. I thank Harvard Law School Professor Margo Schlanger for suggesting the methodology used for the Courtlink and Pacer searches. See Appendix B for more detailed information.

${ }^{5}$ The Milliken v. Bradley decision, 418 U.S. 717 (1974), limits virtually all court-ordered desegregation plans to a single school district. The school district is therefore the appropriate level at which to organize the data.
} 
generated from the SDDB. See Appendix B for detailed information on the data sources and construction of these datasets.

\section{Segregation, Public School Enrollment and School District Fi- nance Results}

\subsection{Outcome Variables}

A primary aim of court-ordered desegregation is increasing the extent of contact between white and black students. The extent of contact between the races can be changed via one of two primary mechanisms. First, holding the racial composition of the district fixed, students may be re-sorted among the schools which comprise a district. Court-ordered desegregation achieves racial integration by this type of re-sorting. For example, magnet school programs and busing produce integration by re-sorting students among schools with a district.

The sorting of students within a district is measured using the dissimilarity index, defined as

$$
D_{t}=\frac{1}{2} * \sum_{t=1}^{n}\left|\frac{b_{i t}}{B_{t}}-\frac{w_{i t}}{W_{t}}\right|
$$

where $\mathrm{b}_{i t}$ and $\mathrm{w}_{i t}$ refer to the number of black and white students, respectively, at school $i$ at time $t$ and $\mathrm{B}_{t}$ and $\mathrm{W}_{t}$ refer to the total number of black and white students, respectively, in the school district. $^{6}$

The dissimilarity index ranges from 0 to 1 , with 0 denoting perfect integration and 1 denoting complete segregation. It is interpretable as the percent of black students who would need to be reassigned to a different school for perfect integration to be achieved given the district's overall racial composition. An increase in segregation is reflected by an increase in the dissimilarity index.

The second mechanism by which a dismissal may affect the extent of contact between blacks and whites is by altering the district wide demographic composition . It is well documented that whites responded to desegregation by moving to alternative public school districts or placing their children in private schools. This response, often termed "white flight", increased the level of segregation in many districts.

\footnotetext{
${ }^{6}$ Most of the segregation indices used in this paper measure the sorting of black and white students. The use of black-white indices reflects the fact that court-ordered desegregation primarily focused on integrating black and white students. These indices are calculated omitting students of other races. Alternative nonwhite-white indices, calculated using the entire student population of a district, are also used. As shown below, the results of this paper do not change substantively when the nonwhite-white indices are used in place of the black-white indices.
} 
The racial sorting equilibrium across public school districts and private schools in metropolitan areas therefore reflects the presence of a court-ordered desegregation plan. The termination of a desegregation plan may break this equilibrium and affect segregation levels by changing the racial composition of a school district. A particularly interesting aspect of this potential change is the response of whites. Dismissal of a desegregation plan may cause whites to re-enter a district - a hypothesized phenomenon which I term "reverse white flight". In addition, black enrollment may change if the dismissal alters the value of the educational services provided by the district to black students. District level demographic changes are examined using data on district enrollment by race. Specifically, the $\log$ of $\mathrm{B}_{t}$ and the $\log$ of $\mathrm{W}_{t}$ are used as outcome variables.

The extent of interracial contact within a school district is measured directly by the exposure index

$$
E_{t}=\frac{1}{B_{t}} \sum_{t=1}^{n} b_{i t} * \frac{w_{i t}}{t_{i t}}
$$

where $\mathrm{t}_{i t}$ is the total number of students in school $i$. It is interpretable as the percent of white students in the average black student's school. For a given district, it ranges from 0 to the percent of white students in the district as a whole. It can be viewed as a measure of the extent of contact between the two races. An increase in segregation is reflected by a decrease in the exposure index.

The dissimilarity index and enrollment by race at the district level can be viewed as directly measuring behavioral responses to the end of court-ordered desegregation. The dissimilarity index will primarily capture the response of policy makers. As policies which promote integration, such as busing, are phased out, the dissimilarity index may increase. Changes in enrollment by race at the district level will primarily reflect the response of parents and students. Policy makers have very limited ability to influence the racial composition of a school district.

The dissimilarity index and enrollment by race are therefore the appropriate measures to use in assessing how policy makers and parents, respectively, respond to the end of court-ordered desegregation. The exposure index remains of interest because it summarizes the extent of contact between whites and blacks - a primary goal of court-ordered desegregation. ${ }^{7}$

\footnotetext{
${ }^{7}$ Echenique and Fryer (2005) note that segregation indices such as the dissimilarity and exposure indices suffer from two undesirable properties. First, they depend upon the way in which the larger unit being examined is partioned into smaller units. This is not a significant problem, however, when measuring school segregation because schools provide a natural partion of students (see their footnote \#5). Second, the outcomes do not allow for measuring segregation at the individual level. The authors propose an alternative segregation measure, the spectral index, which can be calculated at the level of the individual. The data required for calculating an index of this type is not available for the sample of districts under a court-ordered desegregation plan used in this paper.
} 


\subsection{Summary Statistics}

There are 571 school districts in the Rossell and Armor survey data, 125 of which were under court-ordered desegregation plans in 1991. Of these 125 districts, 44, or approximately $\frac{1}{3}$, have been dismissed in the post-1990 period. Figure 1 graphs the timing of these dismissals. There were few dismissals prior to 1996 and there is an apparent acceleration in the number of dismissals over time.

Figure 2 maps the geographic distribution of the districts under court-order in 1991 and the dismissal of these districts occurring between 1991 and 2002. While the sample and the dismissals within the sample are spread throughout the country, there is a concentration in the South census region. Southern school districts make up 65 percent of the dismissals, reflecting the fact that a majority of court-ordered desegregation plans were in the South. Appendix Table 1 lists the districts in the sample and dates of dismissal.

Table 1 presents summary statistics for three sets of school districts - those districts under court-ordered desegregation plans in 1991 and subsequently dismissed within the sample range (i.e. in 2002 or before), those under a plan in 1991 and not dismissed within the sample range and those not under court-order in 1991. These groups will be referred to as the "dismissed", "not dismissed" and "not under court-order" groups, respectively.

Comparing the groups' 1990 characteristics is instructive because it indicates how comparable the groups were in the pre-dismissal period. In general, the dismissed and not dismissed districts are quite similar along observable dimensions. Segregation levels, dropout rates, regional composition, racial composition and measures of district affluence such as median household income suggest the two groups are quite comparable. Exceptions to this comparability are 33 percent lower average enrollment for the not dismissed group and a slightly lower probability of a not dismissed district serving a central city.

The districts which lacked a court-ordered plan in 1991 differ in many ways from the districts which had a plan - they have smaller enrollment, a lower percentage of black students, are less likely to be located in the South and are more affluent. There is clear non-random selection into having a court-ordered plan in 1991. Consequently, the subsequent analysis will focus on a comparison of the dismissed and not dismissed districts. The dismissed districts form the treatment group and the districts which remain under court-order will form the control group. ${ }^{8}$ The not under court-order group is dropped from the sample.

\footnotetext{
${ }^{8}$ The difference in the treatment and control group in terms of enrollment and probability of serving a central city is explicitly addressed in the empirical work presented below.
} 
In addition to being justified based on observables, the sample restriction avoids potential bias arising from the legal trend making voluntary desegregation plans less viable for those districts not under court-order. Districts under court-order are not affected by the legal standing of voluntary desegregation plans. If districts operating voluntary desegregation plans are experiencing changes in the outcome variable, such as the level of segregation, as a result of the changing legal status of voluntary plans, they will not form a valid control group for the set of dismissed districts.

Figure 3 plots the trends of the outcome variables. Tentative conclusions about the impact of the end of court-ordered desegregation can be drawn from the figure. Panel A plots the trend of the mean dissimilarity index for the three groups. The not dismissed and dismissed groups have similar trends through the early the 1990s. By the mid 1990s, the dismissed group is experiencing a more rapid increase.

As shown in the figure, the relative increase in the dissimilarity index of the dismissed group appears associated with the cumulative number of dismissals. The figure provides suggestive evidence that the end of court-ordered desegregation is producing a re-sorting of students which increases segregation.

Panel B plots the percent of enrollment that is white. All three groups trend downward throughout the entire sample period, reflecting national demographic trends. The similar trends of the dismissed and not dismissed groups suggest that dismissal of plans does not alter the demographic composition of school districts. There is no indication of "reverse white flight".

Panel C plots the black-white exposure index. The black-white exposure indices trend downward in a similar fashion for all three groups. The similarity of the trends suggests that the decrease in black-white exposure over this period is primarily the product of the demographic trends apparent in Panel B, not the end of court-ordered desegregation.

Panel $\mathrm{C}$ also plots the white-white exposure index for the entire sample. The white-white exposure index is interpretable as the percent of white students in the average white student's school. The index has a trend similar to that of the black-white exposure indices, indicating whites are experiencing a decrease in contact with whites similar to the decrease being experienced by blacks. This strengthens the claim that the downward trend in black-white exposure is primarily a product of demographic changes.

The increase in the dismissed group's dissimilarity index apparent in Panel A mechanically decreases black-white exposure. Panel C suggests that this decrease is inconsequential compared to the decrease in exposure resulting from demographic changes.

The formal econometric analysis presented below supports the conclusions drawn from Figure 3. The end of court-ordered desegregation produces a significant re-sorting of students which increases 
segregation as measured by the dissimilarity index. Nevertheless, dismissals have only a limited impact on black-white exposure and no impact on school district demographic composition.

\subsection{Empirical Model}

The empirical model is

$$
y_{i t}=\alpha+\sum_{g=-4}^{6} \beta_{g} D_{g, i t}+\delta_{i}+\theta_{j t}+\epsilon_{i t}
$$

where $y_{i t}$ is the outcome variable for district $i$ at time $t, \delta_{i}$ is a vector of district fixed-effects, $\theta_{j t}$ is a vector of Census region $j$ - year $t$ fixed-effects, $D_{g, i t}$ is a dummy variable equaling one if district $i$ at time $t$ was released from its desegregation order $g$ years ago ( $g=0$ denotes the year of dismissal). $D_{6, i t}$ equals one for all years $t$ in which it has been 6 or more years since district $i$ was released from its desegregation order. The $\beta$ vector is the parameter of interest.

The $\beta$ vector traces out the adjustment path from the under court-ordered desegregation plan equilibrium to the new post plan equilibrium. There are several reasons why it is likely that dismissal of a court-ordered plan will result in more complex dynamics than a simple discrete shift in the outcome variable (as would be implied by a model which replaced the $D g$, it $_{\text {vector with a }}$ single indicator variable for dismissal).

Many of the dismissals explicitly stipulate a gradual elimination of the desegregation plan. An extreme example is Indianapolis, where the court-ordered plan is being phased out one grade at a time over a thirteen year period. There are also reasons to believe that frictions may prevent immediate adjustment. Parents may wish their children to continue to attend the school in which they were enrolled before the dismissal. Shifts in attendance patterns resulting from changes in choice of residential location will evolve slowly. The empirical estimates strongly support the hypothesis that dismissals result in a gradual, incremental, adjustment in segregation rather than a discrete shift.

The district fixed-effects control for time-invariant district characteristics such as community preference for racial integration. The Census region-year fixed-effects control for shocks common to districts at the region-year level such as demographic shifts. Time-variant variables such as demographic information may be endogenous to the dismissals and therefore do not enter the model.

The identifying assumption of the model is that, absent dismissal, the dismissed districts would have experienced outcomes similar to the control districts, conditional on the district and regionyear fixed-effects. District-specific trends in the outcome variable are the most likely violation of 
the identification assumption. Specifically, if treated and untreated districts are systematically trending differently, the identifying assumption may be violated.

In order to control for such trends, the following specification is estimated

$$
y_{i t}=\alpha+\sum_{g=-4}^{6} \beta_{g} D_{g, i t}+\delta_{i}+\theta_{j t}+\lambda_{t} * X_{i}+\epsilon_{i t}
$$

where $X_{i}$ is a vector of district-specific characteristics as of the first year the district appears in the sample and $\lambda_{t}$ is a vector of time-varying coefficients. The specification controls for district-specific trends using the base period characteristics of the districts. For example, districts with higher than average levels of poverty may experience more rapid loss of white enrollment. Such a situation would induce a negative trend in the exposure index in high poverty districts. A measure of the poverty rate from the pre-dismissal period, entered into the model with a time-varying coefficient, controls for the presence of such a trend.

The typical approach to estimating a panel data model like the one above would be to estimate via deviation from the mean. The estimates presented here, however, are estimated via firstdifferencing the data to remove the district fixed-effect. The first-difference estimator is used in response to severe serial correlation in the model's error term. Estimation by the first-difference estimator yields considerable efficiency gains relative to estimation by deviation from the mean (Wooldridge 2002). Standard errors are clustered at the school district level in all results reported below (Betrand, Duflo and Mullainathan 2004).

\subsection{Segregation Results}

Estimation of the empirical model provides strong evidence that segregation increases in response to the dismissal of a desegregation plan. Table 2 presents the results for the dissimilarity index. Each column corresponds to a different specification and presents the full vector of pre and post dismissal coefficients. Pre(-4) denotes the coefficient on the indicator variable for four years prior to dismissal, while Post(0) refers to the year of dismissal.

Column (1) includes school district fixed-effects and region-year effects. Column (2) adds a vector of base period school district characteristics interacted with a full set of year indicator variables (see equation (4)). The base period characteristics are location in a central city, percent of students who are white, percent of students who are hispanic, number of enrolled students and the number of enrolled students squared. ${ }^{9}$ Student enrollment is a crucial control given the difference

\footnotetext{
${ }^{9}$ Numerous other district characteristics, such as median household income, were used in unreported specifications.
} 
in enrollment between the treatment and control groups.

Figure 4, Panel A graphs the results of column (2) and reveals that dismissal results in a resorting of students which increases segregation. Dismissal of a court-ordered plan has no effect on segregation in the pre-dismissal period and produces a gradual, linear increase in the postdismissal period. The point estimates for the pre-vector are small in magnitude and estimated imprecisely. The post-vector coefficients increase with the time from dismissal. The sharp trend break around the time of dismissal suggests the estimates reflect the causal impact of dismissal.

The estimated impact of the dismissal of a court-ordered desegregation plan on the dissimilarity index grows from .008 in the year of dismissal to .075 four years after dismissal. While the post $(0)$ coefficient is statistically insignificant, the post(1) is significant at the 15 percent level and the remaining coefficients are significant at the 5 percent level or better.

The magnitude of the effect can be interpreted in several ways. The change in the dissimilarity index four years after dismissal is equal to 21 percent of the index sample mean and to 42 percent of the 1991 cross-sectional standard deviation of the index.

Another interpretation involves comparison to the change in the dissimilarity index resulting from the implementation of desegregation plans in the 1960s, 70s and 80s. Unreported results which replicate the specification estimated in Reber (2002) on the sample of school districts used here suggest that the long-run effect of the implementation of a desegregation order on the dissimilarity index is approximately -.15 (this result is very similar to the balanced panel results presented in Reber). Using this result as a metric, the dismissal of a desegregation plan reverses approximately $\frac{1}{2}$ of the long-run effect of the plans implementation. It is important to note that the estimates of this paper represent the short-run effect of dismissal. The long-run effect may be larger.

The remaining columns on Table 2 display five robustness checks. The first, displayed in column (3), addresses the difference between the treatment and control groups in mean enrollment and probability of serving a central city. The sample is restricted to the set of districts with enrollment exceeding 10,000 in 1991. The restriction eliminates a number of small districts, primarily from the control group, and provides the treatment and control groups with a common support in regards to enrollment. With the restriction the dismissed districts have an average enrollment of 63,690 and 63 percent serve a central city. For the not dismissed districts, the figures are 56,152 and 64 percent.

The second robustness check, displayed in column (4), weights the data by student enrollment. The third, displayed in column (5), includes a full set of district-specific linear trend terms to assess

The results are not sensitive to the exact set of characteristics chosen. 
if district-specific trends in the outcome variable are biasing the estimates.

The fourth, displayed in column (6), uses a balanced panel of districts and includes dismissed districts only if they contribute to the identification of the entire dismissal vector. In the standard specification, the individual coefficients of the dismissal vector are not all identified by the same set of districts. For example, districts dismissed in 2000 do not contribute to the identification of the 2 through 4 years post-dismissal coefficients. It is possible that the increase in the treatment effect with time from dismissal is a spurious result of the differing set of districts identifying the parameters. The final robustness check, displayed in column (7), replicates column (2) using the nonwhite-white dissimilarity index in place of the black-white dissimilarity index.

The results are robust to all of the above specifications. ${ }^{10}$ The balanced panel specification, in column (6), is a relatively important robustness check. These coefficient estimates are plotted in Figure 4, Panel B. The figure displays a sharp trend break at the time of dismissal, again suggesting dismissal results in a causal increase in segregation.

The changes in the dissimilarity index can be viewed as primarily reflecting the response of school district policy makers to the dismissal of a desegregation plan (e.g. ending busing plans). In contrast, there is no evidence of a response by black, non-white or white parents and students. Table 3 presents the results of estimating the empirical model with the log of enrollment by race as the dependent variable. The point estimates are uniformly imprecise. The school enrollment equilibrium, heavily influenced by the imposition of desegregation plans in many metropolitan areas, is not broken by the dismissal of the plans in the short run. There is no evidence of "reverse white flight".

The exposure index measures the extent of contact between the races. It can be viewed as incorporating the net effect of changes in the sorting of students across schools and changes in the school district wide demographic composition. Table 4 presents results for the exposure index with specifications otherwise identical to those on Table 2.

Figure 5, Panel A graphs the results of column (2). Unlike the dissimilarity index estimates, there is some indication of a downward trend in the pre-dismissal period, although the estimates in the pre-dismissal period cannot be distinguished from zero and there does appear to be a trend break around the time of dismissal.

Six years after the termination of a desegregation plan, the exposure index has decreased by

\footnotetext{
${ }^{10}$ The results are also robust to replacing the census region year interactions with either census division year interactions or Federal Circuit Court year interactions. The thirteen Federal Circuit Courts of Appeal, which have historically issued numerous decisions on desegregation cases, often hold differing legal opinions. A school district's Circuit may influence how its court-ordered desegregation plan functions. The Federal Circuits are therefore a reasonable alternative definition of region.
} 
.034 , indicating the average black student in a dismissed district is attending a school with $3 \frac{1}{2}$ percent fewer white students - a rather limited increase in segregation. The point estimates for one through six years after dismissal are all significant at the 5 percent level. The effect six years post-dismissal is equal to approximately 9 percent of the sample mean of the exposure index and approximately 15 percent of the 1990 cross-sectional standard deviation of the index.

The estimated long-run effect of desegregation order implementation on the exposure index is .06 (again based on replication of the specifications used in Reber (2002)). Dismissal therefore reverses approximately $\frac{1}{2}$ of the long-run effect of desegregation as measured by the exposure index.

The results for the exposure index are generally robust, although there is a significant loss of precision when the sample is restricted to districts with enrollment greater than 10,000 and when district-specific linear time trends are included.

Figure 5, Panel B plots the coefficients from the balanced panel specification. The figure displays a much sharper trend break at the time of dismissal than Panel A, which plots the results from the full sample. The sharp break suggests that dismissal results in a causal decrease in the exposure of blacks to whites.

The above estimates implicitly assume that the three Supreme Court decisions do not effect the enforcement of desegregation plans while districts remain under court-order. This is consistent with a literal reading of the decisions. It is possible, however, that the decisions altered the level and/or effectiveness of enforcement. Both plaintiffs and those defendant school districts interested in maintaining their desegregations plans may be reluctant to engage in aggressive enforcement measures for fear that it would lead to dismissal. Judges may be less willing to aggressively enforce plans given the altered legal environment.

Under this scenario, there are two treatment effects. The first is the direct effect of dismissal. The second is the reduced efficacy of the plans which remain in place. Both the treatment and control group receive this second treatment. The estimates above do not reflect this second treatment effect and therefore potentially represent lower bound estimates of the effect of the end of court-ordered desegregation. Figure 3, Panel A reveals an upward trend in the dissimilarity index of the not dismissed group after 1991. The trend raises the possibility that the Supreme Court decisions reduced the efficacy of enforcement as hypothesized.

A formal method to assess the effectiveness of court-ordered desegregation is to estimate

$$
y_{i t}=\alpha+\sum_{g=1991}^{2002} \kappa_{g} U_{i g}+\delta_{i}+\theta_{t}+\epsilon_{i t}
$$

where $U_{i g}$ is a vector of indicator variables equaling one in year $g$ if district $i$ was under a court- 
ordered desegregation plan in 1991, $\theta_{t}$ is a vector of year indicators, and $y_{i t}$ is the dissimilarity index. The sample is restricted to the set of districts not under court-order in 1991 and those districts under court-order and not dismissed between 1991 and 2002. The $\kappa_{g}$ vector measures the effectiveness of court-ordered desegregation plans utilizing the not dismissed districts as the treatment group and the not under court-order group as the control group. If the $\kappa_{g}$ vector increases over time, it suggests desegregation plans are becoming less effective in the post 1990 period.

Table 5 presents the results of estimating equation (5). The $\kappa_{g}$ vector in column (1) increases with time and is precisely estimated from 1997 forward. Inclusion of region-year effects in column (2), however, greatly attenuates the size of the coefficients and only the 2002 coefficient is estimated precisely. Column (3) includes a vector of base period demographic characteristics interacted with a set of year indicators. The $\kappa_{g}$ vector coefficients are small and uniformly imprecise.

The results in column (1) suggest that the reduced efficacy of enforcement effect is .04 in 2002 (see the final coefficient in column (1)). The upper-bound effect of the end of court-ordered desegregation on the dissimilarity index, for the year 2002, is calculated by adding .04 to the coefficients on Table 2. For column (2) of Table 2, the upper-bound effect is approximately .12 for a district six or more years from dismissal. This upper-bound estimate incorporates both the direct effect of dismissal as well as the reduced efficacy of enforcement effect.

Note, however, that column (2) of Table 5 suggests the reduced efficacy of enforcement effect is approximately .025, not .04, and that column (3) suggests that there is no reduced efficacy. ${ }^{11}$ Regardless, the results on Tables 2 and 4 can be viewed as lower bound estimates of the effect of the end of court-ordered desegregation.

Numerous unreported specifications assess whether the effect of dismissal on the outcome variables considered above differs by region, central city, size of enrollment, segregation levels in the pre-1991 period and numerous other district characteristics. There is no evidence that the effect of dismissal varies by any observable characteristic. Particularly notable is a lack of heterogeneity between southern and non-southern school districts - see Appendix Table 2. The lack of heterogeneity by geographic region is important in interpreting the dropout rate and private school attendance results presented in Section 5.

Viewed jointly, the dissimilarity and exposure index results suggest that court-ordered desegregation fails to significantly increase black-white exposure in the post-1990 period, even as it succeeds in enforcing desegregation as measured by the dissimilarity index. The failure to achieve increased

\footnotetext{
${ }^{11}$ As suggested by Figure 3, Panels B and C, the $\kappa_{g}$ vector coefficients are small and imprecise when the exposure index or log enrollment by race are used as the outcome variable.
} 
exposure is explained by 'white flight' and the declining percentage of white students nationally.

It is interesting to note that federal judges often explicitly use measures such as the dissimilarity index, which measure segregation given the racial composition of the district, to assess the efficacy of desegregation plans. Measures such as the exposure index are typically not used because desegregation plans cannot influence district-level racial composition and hence have only limited ability to influence segregation defined in this manner.

Several limitations of the above estimates should be noted. The post-vector coefficients trace out the transition from the under court-order equilibrium to the new, post desegregation plan equilibrium. If the transition to the new equilibrium takes longer than six years after dismissal, the results underestimate the full, long-run effect. Until additional data become available, this uncertainty cannot be resolved. Note, however, that the results do not indicate any deceleration in the rate of increase in segregation six years after dismissal.

Finally, the segregation index estimates assess the effect of dismissal on segregation between schools. Segregation may also occur within a school. The estimates cannot assess if the court dismissals have had an effect on within school segregation. ${ }^{12}$

\section{Dropout Rate and Private School Enrollment}

The above results suggest that the end of court-ordered desegregation has only a limited impact on the exposure of blacks to whites. There is therefore an expectation that any effect of dismissals on black outcomes operating through peer effects will be limited. This does not mean, however, that the overall impact of dismissals on blacks will be limited.

The dismissal of a court-ordered desegregation plan may alter the quality of the educational inputs received by black students. The re-sorting of black students apparent in the dissimilarity index may, on average, place black students in lower quality schools than they attended while their school district was under court-order.

In addition, as time passed from the Brown decision, desegregation cases began to focus on more than racial integration. The adequacy of financial funding for minority students and minority student achievement became explicit goals. The 1977 Milliken II decision allows courts to mandate spending on compensatory educational programs for minority students (Orfield and Eaton 1996). The Freeman decision explicitly allows courts to consider the "quality of education" in deciding

\footnotetext{
${ }^{12}$ Court-ordered desegregation focuses heavily on segregation between schools. As a result, it seems likely that the court-order dismissals will have little impact on within school segregation. Alternatively, Clotfelter, Ladd, Vigdor (2003) present evidence that between and within school segregation are substitutes. After a dismissal, school district officials, no longer able to implement between school desegregation, may attempt to reduce within school segregation.
} 
whether or not to release districts from their desegregation plans (Lindseth 2002; Parker 2000).

When a district is released from its plan, it no longer has an independent body, the courts, constantly monitoring its performance in regards to the educational outcomes of minority students. This may reduce the effort and resources expended on minority students. The end of courtordered desegregation may therefore have a significant impact on black student outcomes even in the absence of a significant change in the exposure of blacks to whites.

\subsection{Outcome Variables}

A two-period panel, utilizing the 1990 and 2000 Census data, is used to examine the effects of court dismissal on dropout rates by race and private school attendance by race. The status dropout rate is defined as

$$
S_{d t}=\frac{\operatorname{Drop}_{d t}}{\operatorname{Tot}_{d t}}
$$

where $\operatorname{Drop}_{d t}$ is the number of civilian 16 - 19 year olds living at time $t$ in the area served by district $d$ who are not enrolled in high school and do not hold a high school degree and $T o t_{d t}$ is the total number of 16 - 19 year old civilians. The status dropout rate is a measure of the stock of dropouts residing in a given school district.

The SDDB is a unique source of information on private school attendance because it tabulates private school attendance by the public school district in which a student resides, not where the student attends school. The private school attendance rate is defined as the percent of total enrolled students residing in a district who are enrolled in private school and therefore summarizes the percent of potential students each public school district has enrolled in private school.

\subsection{Summary Statistics}

Table 6 presents 1990 summary statistics for black students in districts under court-order in 1991. Means are presented for two groups, those districts dismissed between 1991 and 1999 and those not dismissed in this time frame. The first group forms the treatment group and the second group forms the control group. These are slightly different treatment and control groups than those used in section 4 and displayed on Table $1^{13}$.

The table displays the statistics for both the full sample and the set of districts outside the south census region. The regional breakdown is motivated by the results, presented below, that dismissal

\footnotetext{
${ }^{13}$ The 2000 Census data was collected in the spring of 2000 - during the 1999 - 2000 school year. Districts dismissed in 2000, 2001 and 2002, which are part of the treatment group in the CCD 1987-2002 panel used in section 4, are part of the control group for the SDDB 1990 and 2000 panel used in this section.
} 
has an impact on black dropout rates and rates of private school attendance only outside the south. The table reinforces the conclusions drawn from Table 1 - the dismissed and non-dismissed districts are remarkably similar along observable dimensions in the 1990 pre-dismissal period.

Figure 6, Panel A, plots the trends in the black status dropout rate for four groups: the south dismissed and not dismissed groups and the non-south dismissed and not dismissed groups. The south dismissed and not dismissed groups and the non-south not dismissed group all trend downward with a similar slope and have similar values, between .11 and .13, in 2000. Nationally, the black status dropout rate held constant at approximately 12.5 percent over the course of the 1990s (NCES 2001). The three groups appear to be converging with the national black dropout rate during the 1990s. The non-south dismissed group, in contrast, is flat over the period. This difference in trends is suggestive evidence that dismissal of a court-ordered desegregation plan increases black dropout rates outside the south.

\subsection{Empirical Model}

The ideal two-period panel model would utilize the micro long form census data and estimate at the level of individual students

$$
y_{k i t}=\alpha+\beta L_{i t}+\delta_{i}+\theta_{j t}+\rho X_{i t}+\eta M_{k i t}+\varepsilon_{k i t}
$$

where $y_{k i t}$ is the outcome (e.g. dropout rates) of student $k$, in district $i$ at time $t, X_{i t}$ is a vector of district level covariates and $M_{k i t}$ is a vector of student level covariates. $L_{i t}$ is equal to the years since dismissal, relative to 2000, interacted with an indicator variable for the year 2000. For instance, a district dismissed in 1996 has $L_{i t}=4$ when $\mathrm{t}=2000 . \quad \beta$ is the coefficient of interest.

Unfortunately the micro census data does not contain a school district identifier. ${ }^{14}$ The SDDB, however, allows for estimating the pooled regression which follows from equation (7)

$$
\bar{y}_{i t}=\alpha+\beta L_{i t}+\delta_{i}+\theta_{j t}+\rho X_{i t}+\eta \bar{M}_{i t}+\bar{\varepsilon}_{i t}
$$

$\bar{y}_{i t}$ and $\bar{M}_{i t}$ are district level means of the student level variables $y_{k i t}$ and $M_{k i t} .{ }^{15}$

\footnotetext{
${ }^{14}$ The micro census data could be matched to school districts in a procedure similar to that used in Guryan (2004). Unlike the sample used in Guryan (2004), the sample used here contains medium and small sized districts. The matching procedure, when performed with the public use micro data, would produce significant measurement error for these districts.

${ }^{15}$ Due to a quirk in the construction of the SDDB and differences between the 1990 and 2000 versions of the data, the average status dropout rate for district $i$ is measured for 16 to 19 year olds, while the covariate averages, $\bar{M}_{i t}$, are measured for all children. See Appendix B for a more through discussion of this and related data issues.
} 
The identifying assumption of the model is that, absent dismissal, the dismissed districts would have experienced dropout rates similar to that of the non-dismissed districts, conditional on the covariates. The most likely violation of this assumption is district-specific trends in the outcome variable correlated with dismissal.

To assess this threat to the causal interpretation of the empirical estimates it would be preferable to examine the trends in the black dropout rate for the treatment and control groups in the period before the dismissals began. The 1980 school district tabulation of the Census does not permit calculating dropout rates by race. It does permit calculating dropout rates for all races.

Figure 6, Panel B, plots the trend in dropout rates for all races from 1980 to 2000. The plot reveals that from 1980 to 1990, the pre-dismissal period, the treatment and control groups in the south and non-south trend in a very similar fashion. The similarity in the pre-trends provides supportive, although not conclusive, evidence in favor of the identifying assumption.

The empirical model is quite similar to that employed in section 4. Two differences, however, bear mention. First, because the model uses pooled data, the observations are weighted by cell size. Weighting may improve the efficiency of the estimates. ${ }^{16}$ In addition, weighting more closely mimics the motivating micro-level regression, equation (7). ${ }^{17}$

Second, the model includes time-varying covariates. The interpretation of the results differs depending on whether time-varying covariates are included. If they are not included, the estimated effect is the net effect of dismissal on the outcome variable. If they are included, the estimated effect is the effect of dismissal holding student characteristics constant (i.e. controlling for demographic shifts). Results of the model with and without time-varying covariates are presented.

\subsection{Black Dropout Rate Results}

Estimation of the empirical model provides clear evidence of an increase in black dropout rates in dismissed districts. Table 7 presents these results. The four panels display different versions of the empirical model. The columns display results with different controls included. Column (1) contains only the district fixed effects and a year fixed effect. Column (2) adds a vector of census region-year interactions and a central city-year interaction. Column (3) adds a vector of

\footnotetext{
${ }^{16}$ Under the assumption that the errors in the motivating micro regression, equation (7), are i.i.d., weighting leads to efficiency gains by reducing the heteroscedasticity in the error term produced by pooling the data. Weighting the estimates appearing on Table 9 has little impact on the $\beta$ point estimates, but generally doubles the size of the t-statitic, providing support for the above assumption.

${ }^{17}$ The district level data used in the 1987 - 2001 CCD panel model are not individual level data pooled to the district level. The segregation and other outcome measures are intrinsically district level measures. There is no rationale for weighting these models on efficiency grounds and they are therefore not weighted. Note that, as displayed on Tables 2 and 4, columns (4), the segregation estimates are insensitive to weighting.
} 
1990 school district characteristic-year interactions. These interaction terms control for trends in the outcome variable associated with the given characteristic. The specification is analogous to equation (4), from section 4.

Column (4) adds a vector of time-varying student level covariates. These covariates control for demographic shifts. Several of the covariates, such as the percent of parents foreign born and percent of children born out of state, explicitly attempt to control for migration. Additional student level covariates include mother's education, indicator for being beneath the poverty line and household income and household income squared.

Panel A displays the results of estimating the primary model, equation (8). Column (3) indicates that dismissal increases the dropout rate by .0036 for each year since dismissal, although the estimate is only marginally significant at the 10 percent level. To interpret this result consider a district which was dismissed in 1996. Such a district, which is four years post dismissal (the average years since dismissal in the sample, conditional on being dismissed, is 3.5), will experience a black dropout rate approximately .015 higher than if it had not been dismissed. The mean dropout rate for dismissed districts in 1990 is .15, implying that dropout rates increase by approximately 10 percent. Virtually all of the dismissed districts were dismissed in 1994 or after, suggesting that the results should not be extrapolated beyond 6 years since dismissal.

Panel B allows the effect of dismissal to vary by region. The results are striking. All of the increase in dropout rates associated with dismissal is generated by districts located outside the South Census region. A non-southern district experiences an increase of .01 for each year post dismissal. The estimate is quite precise. This suggests that a non-southern district four years post dismissal will have experienced an increase of .04 in the rate of blacks dropping out, an increase of approximately 25 percent from the 1990 mean.

Southern districts do not experience a change in the black dropout rate as a result of being dismissed. The estimates for the south are small and cannot be distinguished from zero. The estimates are precise enough, however, to rule out any sizeable increase in the dropout rate. The 95 percent confidence interval for southern districts, using the estimates in column (3), is $\{-.005$, $.001\}$. The upper bound effect, four years post dismissal, is therefore less than $\frac{1}{2}$ of a point increase in the black status dropout rate.

It is unlikely that dismissal causes a single discrete change in dropout rates. Desegregation plans are often phased out over time and any change in the school environment likely occurs gradually. Panel $\mathrm{C}$ tests this hypothesis by estimating specifications which include both the years since dismissal variable of equation (8) and an indicator variable equal to one if the district has been dismissed. These specifications allow the data to determine if an intercept shift model or a 
linear, years since dismissal parameterization is correct.

The intercept shift model is decisively rejected in favor of the years since dismissal parameterization. In all specifications, the linear dismissal coefficients are statistically significant, typically at the 1 percent level, while the indicator dismissal coefficients are imprecisely estimated. The increase in the dropout rate is a function of time since dismissal.

Panel D reports the results of a falsification test. The effect of dismissal is parameterized as an intercept shift. In addition to the dismissed indicator, the specifications include a placebo indicator equal to one if the district was dismissed after 1999. If the increase in the dropout rate documented in Panel B is the causal result of being dismissed, the districts dismissed outside the date range of the data should not display an increase in the dropout rate.

The falsification test has two significant limitations. First, it must be estimated using the intercept shift parameterization. The data reject this parameterization in favor of the linear parameterization. Second, there are only five districts in the non-southern placebo group. The falsification test may lack statistical power.

The true non-south indicator coefficient is equal to .04 and is estimated precisely. This result is very similar to that produced by the linear dismissal parameterization for a district four years post dismissal in Panel B. The non-south placebo coefficient is between fifty and forty percent as large as the true dismissal coefficient and is imprecisely estimated. The falsification test supports the conclusion that dismissal results in a causal increase in segregation.

The results are robust to a number of alternative estimation strategies. Estimating without weighting the data, using a lagged dependent variable model, as opposed to the fixed effect specification $^{18}$, and estimating the model with the sample restricted to only non-southern districts generates results consistent with those appearing on Table $7 .{ }^{19}$

\subsection{Black Private School Attendance Results}

The empirical model provides evidence that dismissal increases the rate of private school attendance for black students in the non-south, but not in the south. These results are presented on Table 8. Using the estimates in column (3) of panel B, the typical non-southern district four years since dismissal experiences an increase of .01 in the rate of private school attendance. Given the

\footnotetext{
${ }^{18}$ Guryan (2001) demonstrates that if treatment is a function of either time-invariant characteristics or a lagged dependent variable, then a fixed effect model and a lagged dependent variable model will provide an upper and lower bound of the true treatment effect.

${ }^{19}$ An exception is the point estimates for the non-south placebo variable in Panel D. In some unweighted specifications, the placebo coefficient is similar in magnitude to the true dismissed coefficient. Across a wide range of unweighted specifications, however, the placebo coefficient never obtains statistical significance.
} 
1990 mean of .07, this implies an increase of approximately 15 percent.

The estimates are precise enough to rule out any sizeable increase in the rate of black private school attendance in the south. The 95 percent confidence interval for southern districts is $\{-.0014$, $.0025\}$. The upper bound effect is therefore a 1 point increase in the rate of black private school attendance for a southern district four years post dismissal.

The results for private school attendance are somewhat less robust than those for the dropout rate. The indicator treatment parameterization, presented in Panel C, produces no indication of an effect of dismissal. The results are also less robust to estimation without weights.

\subsection{White Dropout and Private School Attendance Rate Results}

There is no evidence that dismissal of a desegregation plan has an effect on white children's school attendance patterns. ${ }^{20}$ These results are presented on Table 9. Most interesting are the results for private school attendance. The public school enrollment results, presented in section 4, similarly fail to find any evidence of a change in white school attendance patterns, suggesting dismissal of court-ordered desegregation plans does not reverse the "white flight" sparked by their implementation.

\subsection{Endogenous Migration}

The presence of migration endogenous to dismissal would alter the interpretation of the results presented in this section. Table 10, Panel A, assess the extent of black student migration. The empirical model is the same as that used above. Columns (1) and (2) examine the effect of dismissal on the log of 16 - 19 year olds residing in the district. Column (1) suggests that each year of dismissal causes an increase of approximately 1.5 percent in the population of black 16 19 year olds residing in non-southern districts. Column (2) reveals that the results are not robust to controlling for trends associated with 1990 district characteristics. The point estimate is small and imprecise. ${ }^{21}$

The absence of a change in the quantity of 16 - 19 years does not rule out the possibility of migration. The remaining columns examine the possibility that dismissal induces a change

\footnotetext{
${ }^{20}$ Allowing for heterogeneity by region produces results suggesting dismissal increases white private school attendance in the non-south - see Panel D, columns (1) and (2). The result, however, is not robust to controlling for trends associated with 1990 demographic characteristics or controlling for time-varying covariates - see columns (3) and (4).

${ }^{21}$ The estimates in column (1) and (2) differ from those on Table 4 because they focus on 16 - 19 years residing in the district, while Table 4 focuses on students of all ages enrolled in the public school system. The Table 4 results capture the net effect of migration, changes in the dropout rate and changes in the private school attendance rate. The results here focus only on migration.
} 
in the average demographic characteristics of a district. The point estimates suggest that black mothers are more educated, household incomes are higher and the probability of a black child being beneath the poverty line decreases after a dismissal. These estimates, however, are generally small in magnitude and are uniformly imprecise.

The in-migration evident in column (1) will effect the dropout rate of a dismissed district if the migrants have a different dropout propensity than the students residing in the district prior to dismissal. There are two reasons for believing that the dropout rate estimates are not the result of endogenous migration. First, there is no evidence of in-migration conditional on controlling for trends associated with 1990 district characteristics. The dropout rate estimates are insensitive to these controls, suggesting that migration is not driving the result. Second, the point estimates suggest that any migration increased the maternal education level and affluence of dismissed districts. It is unlikely that such a change would produce increased dropout rate propensities.

Panel B explores the effect of dismissal on the migration of white students. There is no evidence of a change in the quantity of white 16 - 19 year olds. This is consistent with the evidence from section 4 which found no evidence of "reverse white flight".

The remaining columns, however, suggest that the end of court-ordered desegregation may have altered the demographic composition of whites residing in dismissed districts. The probability of a white mother having a college degree increases by approximately 2 percent for a non-southern district 4 years post dismissal and there is an approximately 1.5 percent decrease in the probability of a white child being beneath the poverty line in such a district. This improvement in the demographic profile of white families in dismissed districts is interpretable as a form of "reverse white flight" - the only evidence for the hypothesized return of white families to dismissed districts found in this paper. ${ }^{22}$

\subsection{Property Values}

The exit of black students from dismissed districts, both via dropping out and moving to private schools, suggests that the value of the education provided by a district to black students is reduced by dismissal. The evidence therefore suggests that dismissal of a desegregation plan reduces the welfare of black students and families.

\footnotetext{
${ }^{22}$ Both the private school attendance results and the migration results are sensitive to the exclusion of Cincinnati from the sample. Cincinnati is an outlier among the non-southern dismissed districts in that its desegregation plan was dismissed in 1991, much earlier than other non-southern districts (see Appendix Table 1). While the point estimates are generally robust to the exclusion, there is typically a significant loss of precision, likely reflecting the small number of the non-southern dismissed districts. The dropout rate results are robust to excluding Cincinnati.
} 
A method for estimating the precise welfare consequences of the end of court-ordered desegregation is to examine the impact of dismissal on property values. The termination of a mandatory desegregation plan potentially alters the value of the bundle of non-market goods provided by a school district. This alteration will capitalize into residential housing values (Hamilton 1976). Changes in housing prices therefore provide a summary measure of the welfare impact of the end of a court-ordered desegregation.

This approach is appealing because it produces a market based estimate of the net change in welfare resulting from dismissal. The total market value of changes in the school district, such as reduced funding from other government agencies and a resulting change in local taxation or changes in the quality of education being provided, will be captured by the change in housing prices. Because the empirical results of this paper suggest the impact of the end of court-ordered desegregation is confined to black students and families, it would be useful to examine the change in property values by race. Unfortunately the SDDB does not permit this. Nevertheless, I explore the effect of dismissal on property values without stratification by race.

Extensive unreported estimation, utilizing the empirical framework of this section, produces extremely imprecise estimates of the effect of dismissal on property values (of all races). Property values therefore provide no evidence of a net change in welfare resulting from a dismissal. The lack of evidence may be the result of the inability to analyze the property value data by race. These results are available from the author upon request.

\section{Interpretation}

The results of this paper suggest that dismissal of a court-ordered desegregation plan produces a gradual increase in racial segregation as measured by the dissimilarity and exposure indices. The increase is moderate - approximately $\frac{1}{2}$ of the decrease in racial segregation achieved by the plans implementation is undone.

Dismissal also increases the exit of black students from public schools in non-southern districts, both via dropping out and via entering private school. For both sets of students, dismissal changes the net value of attendance such that the cost exceeds the benefit for students at the margin.

It is likely that the set of students on the margin for dropping out face different relevant outside opportunities than the set on the margin for exiting to private school. For instance, the relevant outside opportunities for those on the dropout margin may be employment while for the second set of students the relevant outside opportunity may be private school attendance. The fact that both sets of students exit at an increased rate makes it less likely that the results are driven 
by a change in the opportunity cost of attendance - for instance increased wages at employment outside of school. It is therefore reasonable to jointly interpret the private school and dropout rate results as indicating that the value of the educational services provided to black students in non-southern districts is reduced by dismissal. This reduction in value constitutes a welfare loss for black students.

No evidence is found of an effect on white student dropout rates or private school attendance rates. There is evidence, however, that dismissal produces a demographic shift among whites in non-southern districts. The education level of mothers increases and children are less likely to be beneath the poverty line. This shift can be seen as a form of "reverse white flight" - dismissal causes more affluent white families to return to dismissed districts.

A limitation of the dropout and private school results is their reduced form nature - they cannot establish the mechanism or channel via which the dismissals are impacting educational outcomes. Despite this limitation, a discussion of possible channels is warranted. Two primary channels exist through which dismissal may negatively impact black student outcomes - peer effects and the quality of educational inputs provided to black students. There are several reasons for believing that peer effects are not the primary channel causing an increase in dropout rates.

First, the estimated decrease in exposure between whites and blacks is small. The typical black student in a dismissed school district experiences only a three and a half percent drop in the percent of white students in his school. In comparison, the initial implementation of desegregation plans increased the exposure of nonwhites to whites by ten to thirteen percent (Reber 2002).

Second, there is no heterogeneity in the response of black-white exposure levels by southern vs. non-southern districts. Districts in the south experience a similar decrease in the exposure of black students to white students, but do not experience a similar increase in black dropout rates.

The conclusion that the decrease in black-white exposure does not explain the increased black dropout rates and private school attendance rates is consistent with recent research. Echenique and Fryer (2005) document that the within school inter-racial contact of black students is non-linear. Once blacks comprise more than twenty-five percent of the population of a school, they experience near complete within school segregation. In schools with more than twenty-five percent black enrollment, like the majority of the schools in the sample used in this paper, changes in district level segregation may not effect the peer group actually experienced by black students. Card and Rothstein (2005) find no evidence that relative exposure to black students impacts black student performance.

The second channel through which termination of a desegregation plan can impact black student outcomes is a change in the quality and quantity of education inputs. The documented re-sorting 
of students across schools in a district may result in blacks, on average, attending schools of a lower quality.

Dismissal may also impact the quality and quantity of educational inputs received by blacks independent of re-sorting across schools. While a district is under court-order, it has an independent body, the courts, constantly monitoring its performance in regards to the educational outcomes of minority students. The removal of court oversight may lead school district officials to reduce both the level of financial resources expended on black students and the level of effort expended on maintaining minority student performance.

An open question raised by the results of this paper is: why do dismissals outside the south result in negative black student outcomes, whereas there is no effect of dismissal in the south? The available data fail to resolve this puzzle. Both regions experienced similar changes in racial segregation. The most promising data source on the non-racial integration aspects of court-ordered desegregation is the school district finance data released annually by the Census Bureau. Extensive unreported estimation, utilizing the empirical framework of section 4 and available from the author upon request, fails to find any evidence of a shift in overall district finances in response to dismissal in the south or non-south. It is still possible, however, that dismissal of a desegregation plan leads to a substitution of expenditures and effort away from minority students (in a manner which leaves overall district finances unchanged). If the extent of this substitution differs by region, it would explain the divergent experiences of the south and non-south in the post dismissal period.

Under this hypothesis, court-ordered desegregation in the 1990s imposed a constraint on the effort and resources targeted at black students in the non-south, but not in the south. There are two possible interpretations. First, it is possible that enforcement of court-mandated plans, in regards to the non-integration aspects such as financial resources, was more rigorous in the non-south. Dismissal therefore has more of an impact in the non-south.

Second, it is possible that the aims of court-ordered desegregation had been internalized by school district administrators in the south, whereas they had not been internalized outside of the south. Under this scenario, school district officials in the south may have continued to provide the effort and financial resources mandated by the desegregation plan after the plan's dismissal. For example, anecdotal evidence suggests school districts often engage in capital investment in minority neighborhoods after the dismissal of a desegregation plan. The Nashville, Tennessee school district pledged to spend $\$ 206$ million on new school construction when it was released from its desegregation plan (Goldring and Smrekar 2002). The Lafayette Parish, Louisiana School Board promised to replace inadequate inner city schools after its desegregation plan ended (NAACP 2000). This type of effort, if it is confined to the south, may explain the divergent regional response to the 
end of court-ordered desegregation. ${ }^{23}$

The data cannot substantiate, or refute, the above hypotheses. The reason for the divergent experiences of the south and non-south will remain speculative until more detailed data becomes available.

Finally, it is important to note that the results of this paper represent the short run response to dismissal. The long run response may differ from the short run response documented here. As more data becomes available, it will become possible to estimate the long run effects of the end of court-ordered desegregation.

\footnotetext{
${ }^{23}$ The school district finance data provides no evidence that dismissed districts increase their capital expenditures in the south or non-south. Capital expenditures in minority neighborhoods, however, could represent substitution away from other capital expenditures, such as building new schools in non-minority neighborhoods.
} 


\section{Appendix A: Brief History of Desegregation Law}

- Plessy v. Ferguson, 163 U.S. 537 (1896). Racial segregation does not constitute discrimination under the 14th Amendment. The "separate but equal" doctrine is established.

- Brown v. Board of Education of Topeka, 347 U.S. 483 (1954). State-imposed segregated schools are "inherently unequal". The "separate but equal" doctrine is struck down.

- Brown II, 349 U.S. 294 (1955). School desegregation shall occur via plans developed by the federal judiciary. No time table for desegregation was set and the meaning of the term desegregation was left ambiguous.

- Civil Rights Act (1964). Discrimination banned in any school receiving federal aid. The Johnson Administration enforced this ban and had the Justice Department initiate numerous desegregation lawsuits.

- Green v. County School Board of New Kent County, 391 U.S. 430 (1968). Racially dual school systems must be "dismantled root and branch." Defined the areas subject to desegregation - facilities, staff, faculty, extracurricular activities and transportation. These areas became referred to as the "Green factors."

- Swann v. Charlotte-Mecklenberg Board of Education, 402 U.S. I (1971). Busing is allowed as a means of achieving desegregation.

- Keyes v School District No.1, Denver, Colorado, 413 U.S. 189 (1973). Requirements established for declaring school systems which lacked legally mandated segregation as having a dual system. Desegregation cases became viable in the north and west where segregation had not been legally mandated.

- Milliken v. Bradley, 418 U.S. 717 (1974). Inter-district desegregation orders are ruled illegal unless discrimination can be proven to have occurred across district boundaries.

- Mid-1970s to 1991. The Supreme Court left desegregation law essentially unchanged between the mid-1970s and 1991. The number of federal court desegregation orders, which peaked in the early 1970s, declined in the late 1970s and early 1980s. The last desegregation order for a large district was San Jose in 1986.

- Board of Education of Oklahoma City v. Dowell, 498 U.S. 237 (1991). The requirements for a district being declared unitary (meaning the district was no longer operating an illegal, racially dual school system) were established. Prior to the ruling, the term had no clear legal meaning. Once a district is declared unitary, it must be released from court control and is no longer legally obligated to maintain a desegregated school district. Even immediate and complete resegregation is acceptable, as long as the district does not state its attendance policies are explicitly aimed at achieving racial segregation. Prior to the decision, it has been widely presumed that districts released from court control had an obligation to maintain a desegregated district (Orfield (2001) pg. 5; Lindseth 2002 pg. 57).

- Freeman v. Pitts, 503 U.S. 467 (1992). Districts may be declared partially unitary by achieving one or more, but not all, of the Green factors. Factors for which the district has achieved unitary status no longer fall under court control. 
- Missouri v. Jenkins, 515 U.S. 70 (1995). Limited enforcement options available to the district courts (for example, efforts to voluntarily induce white students from outside the district to attend district schools are not permissible). The restoration of local school control should be a primary goal of all federal desegregation cases.

\section{Appendix B: Data Appendix}

\subsection{Rossell and Armor Survey Data}

The sample of school districts used in this paper is restricted to the set of districts identified in the Rossell and Armor survey data. I am indebted to Christine Rossell and David Armor for providing me with their data. The original research was funded by the U.S. Department of Education from 1990 to 1993 with Christine Rossell and David Armor as co-principal investigators and Roger Levine and Lauri Steele, American Institutes for Research, as contract managers. Published works using this data file are Rossell (2003), Rossell (2002), Armor and Rossell (2002), Rossell and Armor (1996) and Steel, Levine, Rossell and Armor (1993). The sampling frame for the survey data was the set of U.S. school districts in which two or more schools offer at least one grade level (K-12) in common. 6,392 of the 16,986 districts in the 1989/1990 CCD meet this criterion. Districts with enrollment of 27,750 or greater were sampled with certainty, as were districts which were MSAP (a federal magnet school program) grantee districts. Remaining districts were sampled based on stratum for size and racial composition. Larger districts and districts with diverse racial compositions were oversampled. See Appendix A of Steel and Levine (1994) for details. The original survey sample contained 602 districts. The sample used in this paper contains 571 districts. The discrepancy arises from the fact that several districts included in the original sample do not map into the CCD. For example, the subdistricts of New York City were considered separate districts in the survey sample, but constitute a single district in the CCD. Two districts closed over the time period of the data. These districts remain in the sample until the year of closure. Districts-year observations with insufficient race data were omitted from the estimation sample. Insufficient race data is defined as having the sum of enrollment by race equal to less than 90 percent of total enrollment. The results reported in the paper, however, are unchanged when these observations are included. All observations for Tennessee in 1997 are dropped due to clear error in the racial variables for the entire state. Tennessee ceased to report racial data in 1999 and all Tennessee districts therefore drop out of the sample from 1999 on.

\subsection{Legal Variables}

I construct two district level variables based on the legal status of the school district in relation to court-ordered desegregation plans. The first variable indicates the year the district was dismissed from its desegregation order if it was dismissed in 1991 or after. Many of the dismissals are unitary status declarations. Others are terminations of judicial involvement in the school district without a formal unitary status declaration. In some cases unitary declarations are made and court supervision continues for a limited period of time. The dates of dismissal attempt to reflect the date court supervision of the school district ended. Some rulings involve school districts agreeing to take a certain course of action, for instance making capital investments in minority neighborhoods, over the course of several years. These type of stipulations are not considered court supervision. The second variable indicates whether or not the district was under a court-ordered desegregation plan in 1991, the year of the first of the three early 1990s Supreme Court decisions relating to desegregation. 
I use multiple sources to generate these variables :

1. Ma (2003), a spreadsheet produced by the Harvard Civil Rights Project titled "List of School Districts Previously Under Desegregation Orders Dismissed between 1990 - 2002", is the primary source of the year of dismissal variable. A conversation with Jacinta Ma, the author of the spreadsheet, suggests it is accurate for very large districts, but may not be complete for smaller ones. As a result, I supplement the data in Ma (2002) with information from other sources.

2. The Rossell and Armor data contains a variable indicating if the school district has a desegregation plan as of Oct. 1, 1991. Another variable indicates the source of the plan, in particular whether or not it was a court-ordered plan. The Rossell and Armor data is the primary source of the under plan as of 1991 variable.

3. Appendix $\mathrm{C}$ of Welch and Light contains a bibliography of legal sources for each of the districts in the Welch and Light sample. For some of these districts, a date of court-order dismissal is given.

4. The Civil Rights Division of the United States Justice Department maintains a list of all school desegregation cases currently active to which the United States is a party. The list also contains the names of all school districts involved in each case. The Civil Right Division provided the author with a copy of the list current as of March 8, 2003. Historically, the Justice Department was one of the most active litigants in school desegregation cases. The list almost certainly contains a non-trivial percentage of desegregation cases still active in the federal courts.

5. Legal opinions, both published and unpublished, issued by Federal District and Appeals Courts, and available via Lexis-Nexis and Westlaw, often contain extensive information on desegregation cases.

6. The Federal District Court dockets for desegregation cases typically contain information about the status of the case and the date of dismissal if applicable. The docket numbers, required to obtain the dockets, were obtained in two ways. First, docket numbers appear on opinions issued by Federal District Courts (see above). Second, Courtlink, a service provided by LexisNexis, allows for complex electronic searches of Federal District Court dockets. The dockets are available on Courtlink at varying dates for the different District Courts. Typically the dockets are available from the late 1980s or very early 1990s forward. A search using the following parameters was performed: nature of suit = "440" (denoting the case as civil rights, other), keywords $=$ "school $^{\sim}$ AND segregat $\sim$ OR desegregat ${ }^{\sim}$ OR unitary" (where the ${ }^{\sim}$ is a root expander). The search provided a list of docket numbers, for both active and closed cases, meeting the above criterion. The search is the most sophisticated currently possible. However, there are several potential sources of error in the search. First, cases with no activity in the date range of the database will be missed. Second, the dockets must contain the specified keywords. A very sparse docket from a desegregation case could potential lack the keywords used in the search. Second, while all Federal District Court dockets from the relevant dates appear in the database, they are not updated unless a user specifically requests, and pays, for the update. As a result, a docket concerning a desegregation case that contains the keywords in an entry dated after the docket was initially downloaded into Courtlink and which has not been subsequently updated, will be missed by the search. As a result of these potential sources of error, the search, while the best possible, cannot be 
viewed as generating a comprehensive list of desegregation case dockets. The actual dockets were obtained from PACER, an electronic service maintained by the federal court system. T he methodology of jointly employing Courtlink and PACER was suggested to me by Margo Schlanger, a professor at Harvard Law School and an expert on this type of empirical legal research. Professor Schlanger laid out the precise methodology employed.

7. A variety of published sources, including books, journal articles, newspaper articles, magazine articles, minutes of school board meetings, school budgets, etc. were utilized. In particular, the electronic archives of Education Week, the national publication with the greatest commitment to covering school desegregation issues, was used.

8. Personal communication with school district officials were used in cases when all of the above sources failed to provide sufficient information.

\subsection{School District Data Book}

The School District Data Book (SDDB) is a public school district level tabulation of the U.S. Census which focuses on children (the 2000 version is referred to as the School District Tabulation - STP2). A child is included in a districts tabulation if he/she lives within the territory of the district and his/her grade level is offered by the school district. In 2000, a child is defined as a person age 0 to 17 or a person 18 or 19 years of age who has not graduated from high school. In 1990 a child is defined as a person age 3 to 19 who has not graduated from high school. As noted in the text, the status dropout rate is calculated only for 16 to 19 year olds, while the individual level covariates are tabulated from all children. In addition, several of the individual level covariates are tabulated by household or parents of children as opposed to being tabulated by child. If the pooled regression (equation (7) in the text) was being calculated from micro data, the individual level covariates would be averaged over the total number of children in the district. The following covariates from the SDDB, however, are averaged over the set of parents with children : mother's education and parent foreign born. Each parent with a child contributes a single observation to the calculation of the mean, regardless of the number of children the parent has. Ideally, each child would contribute a single observation to the calculation of the mean. Similarly, the household income variables are averaged over the set of households with children, as opposed to being average over all children. In all of the above cases, the calculated means approximate the true mean calculated over the number of children in the district. One important difference between the CCD data, used in section 4, and the SDDB data, used in section 5, bears mention. The CCD maintains hispanic as a separate racial category along with white, black, asian and native American. The SDDB, however, treats hispanic background as an aspect of ethnicity. An individual of a given race, for instance an individual whose racial category is white, can indicate that she is, or is not, ethnically hispanic. For the purposes of section 5, white refers to non-hispanic white children

and black refers to hispanic and non-hispanic black children. The 2000 SDDB does not contain information on black children separately tabulated by ethnicity. 


\section{References}

Angrist, Josh and Kevin Lang, "Does School Integration Generate Peer effects? Evidence from Boston's Metco Program," American Economic Review, December 2004.

Armor, David J. and Christine H. Rossell, "Desegregation and Resegregation in the Public Schools," in Abigail Thernstrom and Stephen Thernstrom, Beyond the Color Line, pp. 219-258. Palo Alto, CA: Hoover Institution Press, 2002.

Betrand, Marianne, Esther Duflo and Sendhil Mullainathan, "How Much Should We Trust Differences-in-Differences Estimates?" Quarterly Journal of Economics, Vol. 119 Issue 1, Feb. 2004.

Boger, John, "Education's Perfect Storm? Racial Resegregation, High Stakes Testing \& School Inequities : The Case of North Carolina", The Resegregation of Southern Schools? A Crucial Moment in the History (and the Future) of Public Schooling in America Conference Paper, August 2002.

Boozer, Michael A., Alan B. Krueger and Shari Wolkon, "Race and School Quality Since Brown v. Board of Education," Brookings Papers on Economic Activity: Microeconomics, (1992) 269 326.

Card, David and Abigail Payne, "School Finance Reform, the Distribution of School Spending and the Distribution of SAT Scores", National Bureau of Economic Research Working Paper No. 6766, October 1998.

Card, David and Jesse Rothstein, "Racial Segregation and the Black-White Test Score Gap", mimeo, March 2005.

Cherminsky, Erwin, "Courts Must Share the Blame for the Failure to Desegregate Public Schools" The Resegregation of Southern Schools? A Crucial Moment in the History (and the Future) of Public Schooling in America Conference Paper, August 2002.

Clotfelter, Charles, Helen Ladd and Jacob Vigdor, "Racial Segregation in Modern-Day Public Schools" mimeo, July 2003.

Clotfelter, Charles, Helen Ladd and Jacob Vigdor, "Federal Oversight, Local Control, and the Specter of "Resegregation" in Southern Schools", NBER Working Paper 11086, January 2005.

Echenique, Federico and Roland Fryer, "On the Measurement of Segregation", mimeo, Harvard, March 2005.

Frankenburg, Erica, Chungmei Lee and Gary Orfield, "A Multiracial Society with Segregated Schools : Are We Losing the Dream?", Harvard Civil Rights Project Report, 2003.

Glaesar, E.L. and J. L. Vigdor, "Racial Segregation: Promising News", in B. Katz and R. Lang eds. Redefining Urban \& Suburban America: Evidence from Census 2000, Volume I, , 211-234. Washington : Brookings Institution Press, 2003.

Goldring, Ellen and Claire Smrekar, "Shifting from Court-Ordered to Court-Ended Desegregation in Nashville : Student Assignment and Teacher Resources", The Resegregation of Southern 
Schools? A Crucial Moment in the History(and the Future) of Public Schooling in America Conference Paper. August 2002.

Guryan, Jonathan, "Desegregation and Black Dropout Rates", National Bureau of Economic Research Working Paper No. 8345, June 2001.

Guryan, Jonathan, "Desegregation and Black Dropout Rates", American Economic Review, Vol. 94 No. 4, September 2004.

Hamilton, Bruce, "Capitalization of Interjurisdictional Differences in Local Tax Prices", American Economic Review, Vol. 66, No.5, pg. 743 - 753, 1976.

Hoxby, Caroline, "Peer Effects in the Classroom: Learning from Gender and Race Variation," National Bureau of Economic Research Working Paper No. 7867, August 2000.

Hoxby, Caroline, "All School Finance Equalizations are Not Created Equal," Quarterly Journal of Economics (November 2001), 1231 - 1189.

Hanushek, Eric, John Kain and Steven Rivkin, "New Evidence About Brown V. Board of Education: The Complex Effects of School Racial Composition on Achievement,", National Bureau of Economic Research Working Paper No. 8741, January 2002.

Lindseth, "Legal Issues Relating to School Funding/Desegregation" in Rossell, Armor, and Walberg, (eds.), School Desegregation in the 21st Century, pp. 41-66. Westport, Ct.: Praeger Publishers, 2002.

Ma, Jacinta, "List of School Districts Previously Under Desegregation Orders Dismissed between 1990 - 2002" Harvard Civil Rights Project, unpublished draft, 2003. 2002.

Merelman, Richard, "Dis-Integrating American Public School," Education Week, Feburary 6,

Murray, Sheila, William Evans and Robert Schwab, "Education-Finance Reform and the Distribution of Education Resources", American Economic Review, Vol. 88, No. 4, Sept. 1998.

NAACP Legal Defense and Education Fund, Inc. 2000 Annual Report, 99 Hudson St., Suite 1600, New York, NY 10013.

National Center for Education Statistics, "Dropout Rates in the United States: 1999," U.S. Department of Education, Office of Educational Research and Improvement, 2001.

New York Times, "Fighting School Resegregation", Editorial Page, January 27, 2003.

Orfield, Gary, "Schools More Separate: Consequences of A Decade of Resegregation?," Harvard Civil Rights Project Report, 2001.

Orfield, Gary and Susan Eaton. Dismantling Desegregation: the Quiet Reversal of Brown v. Board of Education. New York: New Press: Distributed by W.N. Norton \& Company, 1996.

Orfield, Gary and Chungmei Lee, "Brown at 50: King's Dream or Plessy's Nightmare?," Harvard Civil Rights Project Report, 2004. 
Parker, Wendy, "The Future of School Desegregation," Northwestern University Law Review, vol. 94, no. 4 (summer 2000), 1157 - 1227.

Raffel, "History of School Desegregation" in Rossell, Armor, and Walberg, (eds.), School Desegregation in the 21st Century, pp. 17-40. Westport, Ct.: Praeger Publishers, 2002.

Reber, Sarah, "Court-Ordered Desegregation: Successes and Failures in Integrating American Schools Since Brown," mimeo, March 2002.

Rossell, Christine H., "The Desegregation Efficiency of Magnet Schools," Urban Affairs Review (formerly Urban Affairs Quarterly), vol. 38, May 2003: 697-725.

Rossell, Christine H, "The Effectiveness of Desegregation Plans," in Rossell, Armor, and Walberg, (eds.), School Desegregation in the 21st Century, pp. 67-118. Westport, Ct.: Praeger Publishers, 2002.

Rossell, Christine H and David Armor, "The Effectiveness of School Desegregation Plans, 19681991," American Politics Quarterly, July 1996, 24 (3): 267-302.

Schlanger, Margo, "Inmate Litigation," Harvard Law Review, vol. 116 (Apr. 2003).

Steel, Laurie and Roger Levine, "Educational Innovations in Multiracial Contexts: The Growth of Magnet Schools in American Education, "Report by American Institutes for Research in Behavioral Sciences, Palo Alto, California, 1994.

Steel, Laurie, Roger Levine, Christine Rossell, and David Armor, "Magnet Schools and Issues of Desegregation, Quality and Choice, Phase I: the National Survey and In-Depth Study of Selected Districts," a report to the Department of Education, 1993.

Tushnet, Mark, "'We've Done Enough' Theory of School Desegregation," Howard Law Review, vol. 39 (1996).

Welch, Finis and Audrey Light, "New Evidence on School Desegregation." Unicon Research Corporation and United States Commission on Civil Rights. Washington D.C.: United States Commission on Civil Rights, 1987.

Wooldridge, Jeffrey M., Econometric Analysis of Cross Section and Panel Data, MIT Press, Cambridge, Massachusetts, 2002. 
Figure 1: Desegregation Order Dismissals Post 1990

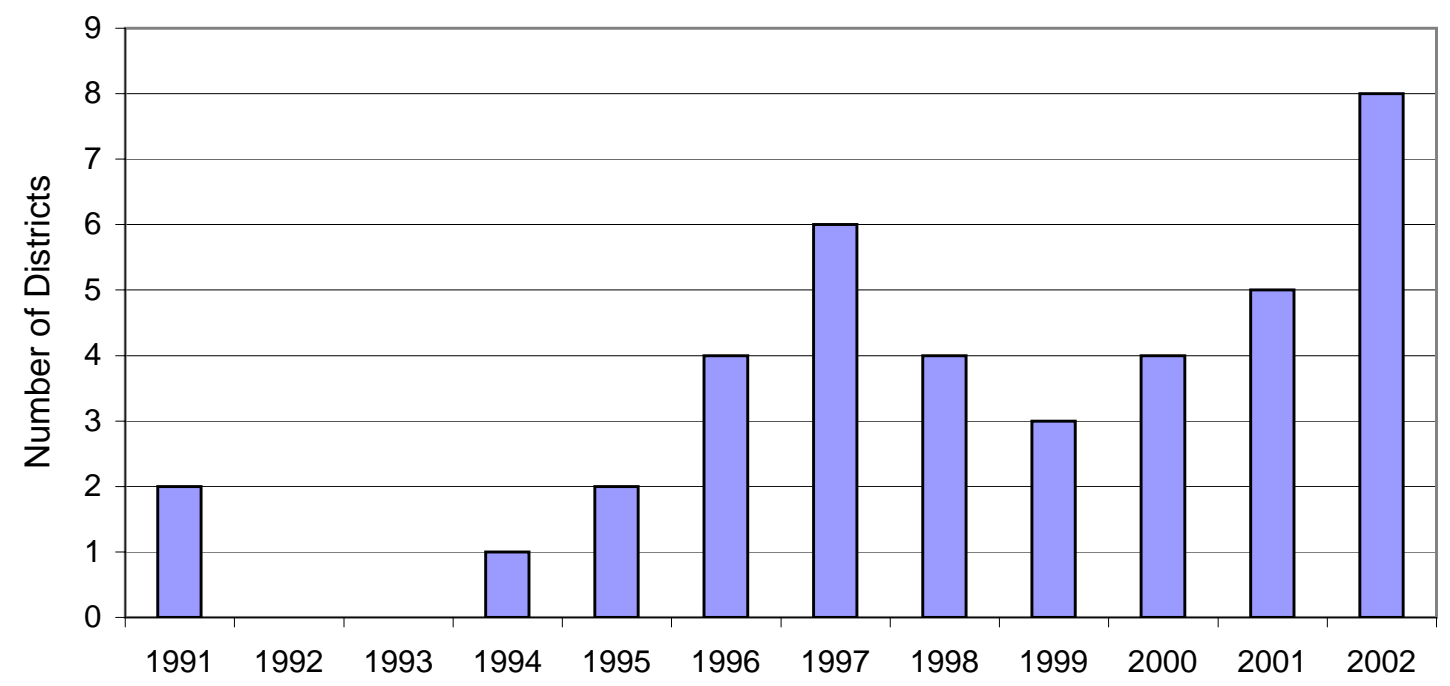

Note. The figure displays the number of dismissals of desegregation plans occurring among the set of school districts in the Rossell and Armor sample which were under a court-ordered desegregation plan at the start of 1991.

Figure 2: Geographic Distribution of Sample and Dismissals

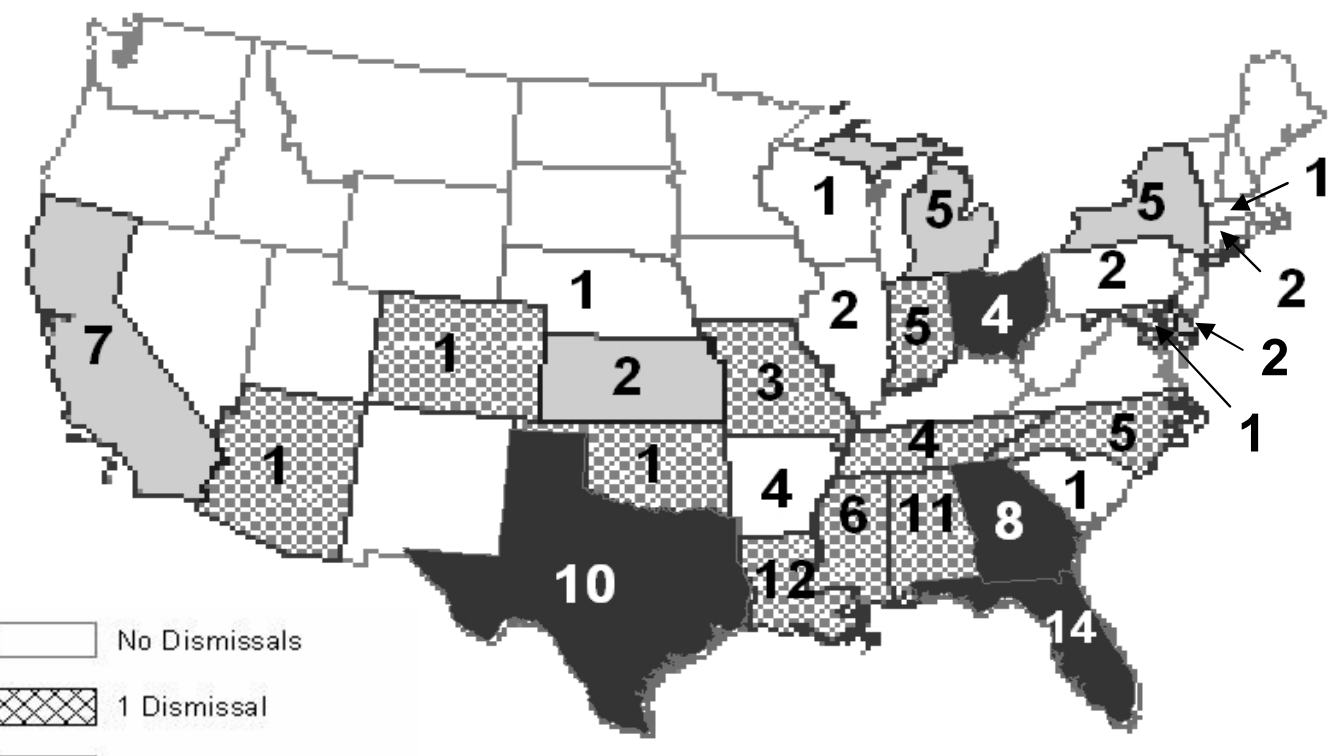

2 Dismissals

3 or More Dismissals

Note. The figure displays the number of dismissals of court-ordered desegregation plans by state from 1991 to 2002 . The numbers within the states are the number of school districts in the state that appear in the estimation sample - i.e. that appear in the Rossell and Armor survey data and were under a court-ordered desegregation plan in 1991. 
Figure 3: Segregation Trends

Panel A: Dissimilarity Index

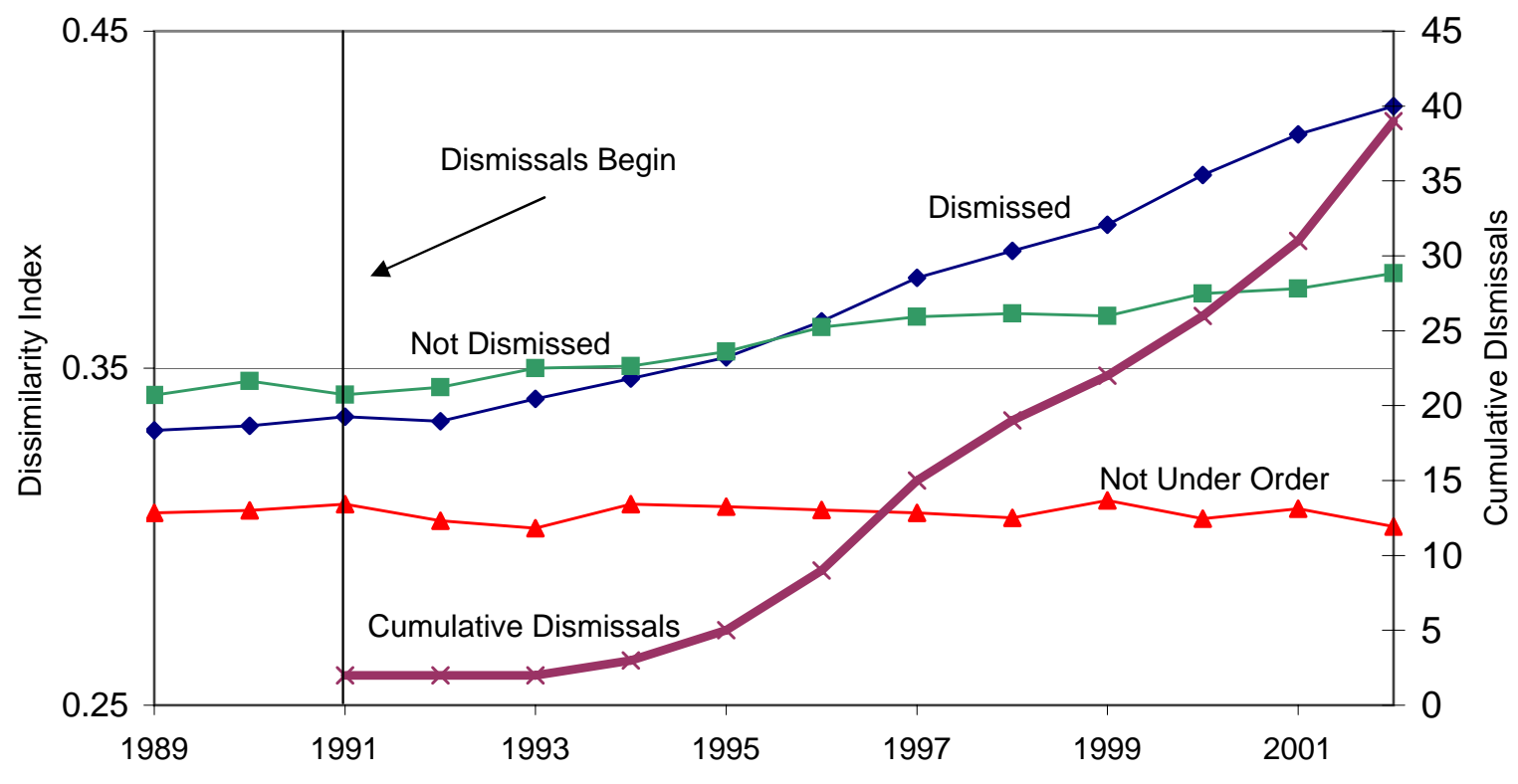

Panel B: Percent White

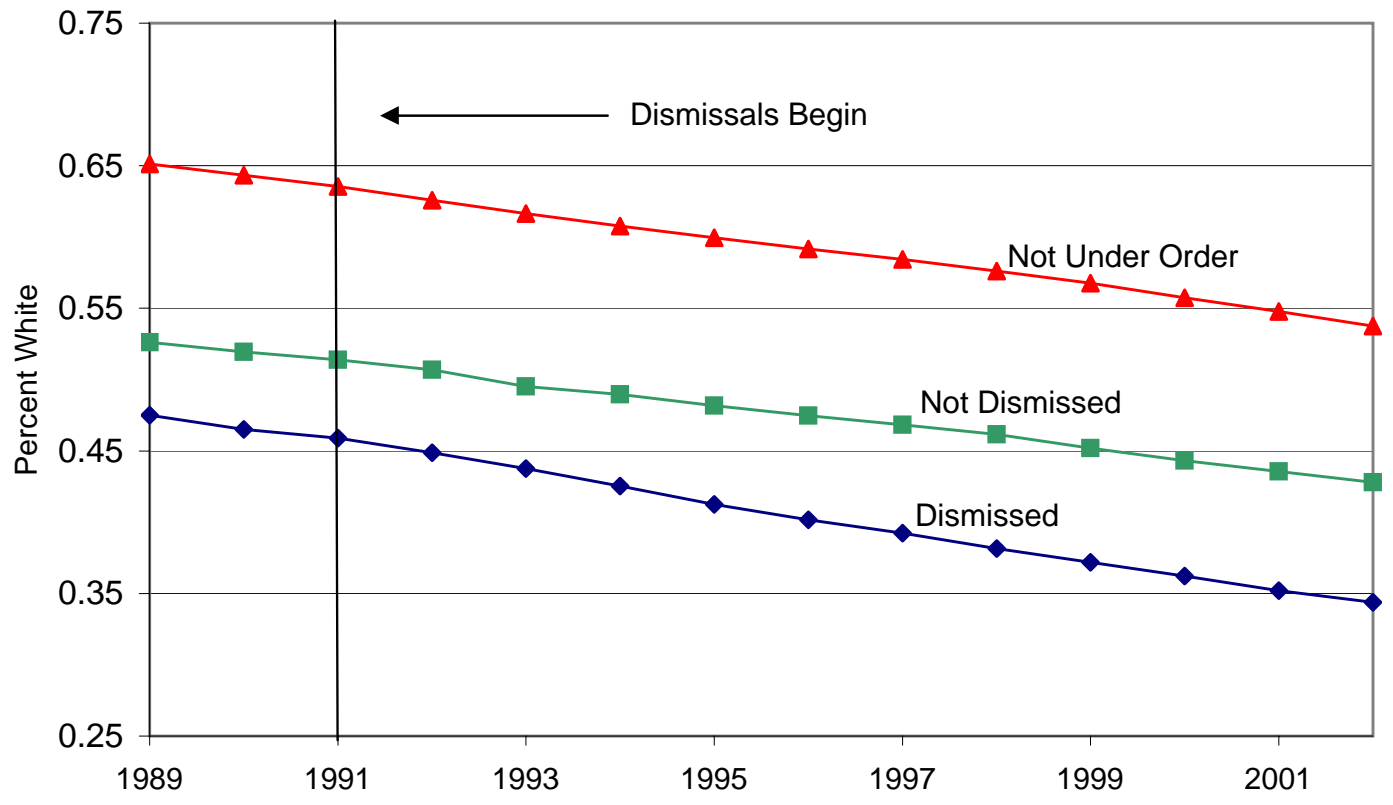

Note. The plots are means for the relevant groups. Dismissed refers to those districts under court-order in 1991 and dismissed from their desegregation plan between 1991 and 2002. Not dismissed refers to those districts under court-order in 1991 and not dismissed from their plans between 1991 and 2002. Not under order refers to those districts not under court order in 1991. The sample of districts is restricted to those in the Rossell and Armor sample which form a balanced panel from 1989 to 2002. 
Figure 3: Segregation Trends

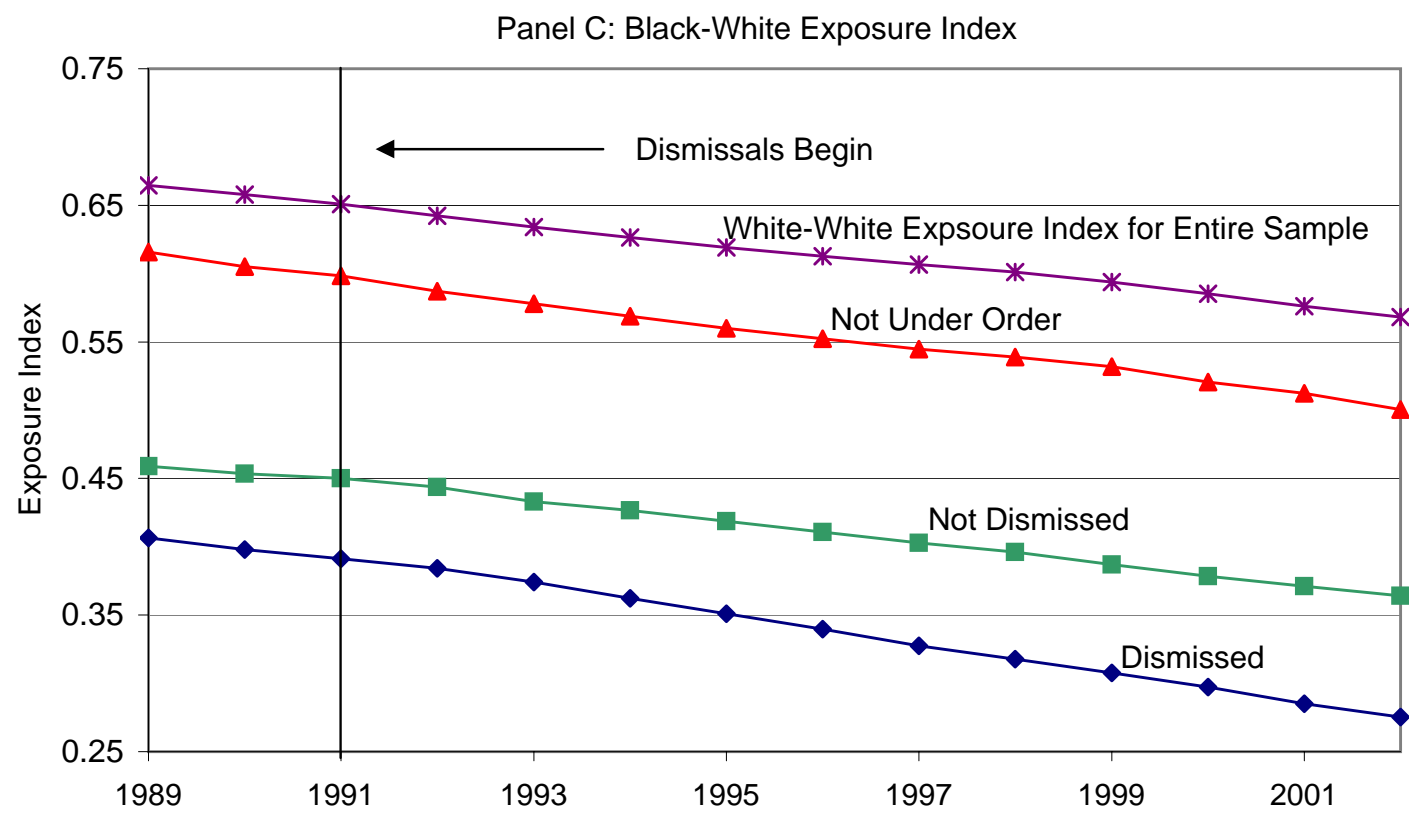

Note. The plots are means for the relevant groups. The dismissed, not dismissed and not under order group plots refer to the black-white exposure index. Dismissed refers to those districts under court-order in 1991 and dismissed from their desegregation plan between 1991 and 2002. Not dismissed refers to those districts under court-order in 1991 and not dismissed from their plans between 1991 and 2002. Not under order refers to those districts not under court order ir 1991. The sample of districts is restricted to those in the Rossell and Armor sample which form a balanced panel from 1989 to 2002. 
Figure 4: Effect of Dismissal on Dissimilarity Index

Panel A: Full Sample

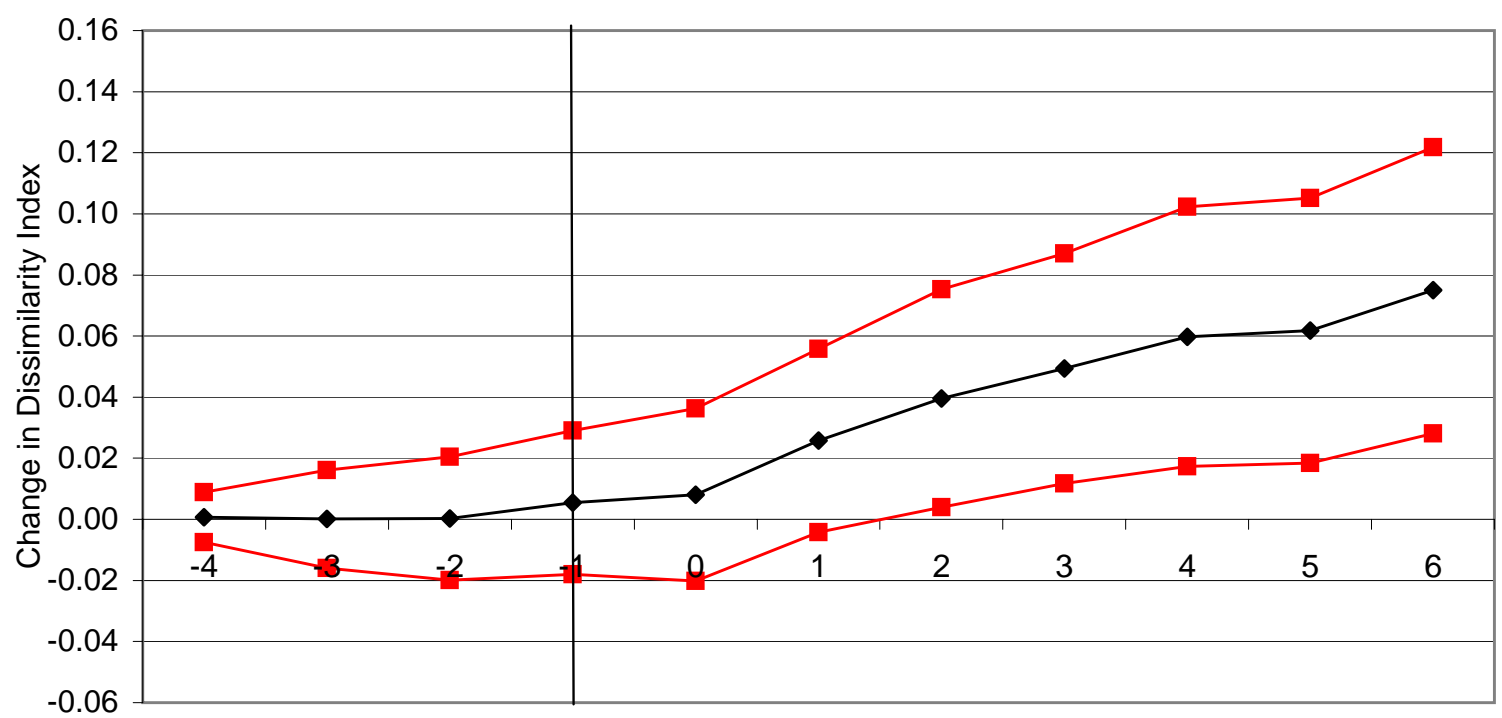

Time Relative to Dismissal ( 0 = Year of Dismissal)

Panel B: Balanced Panel

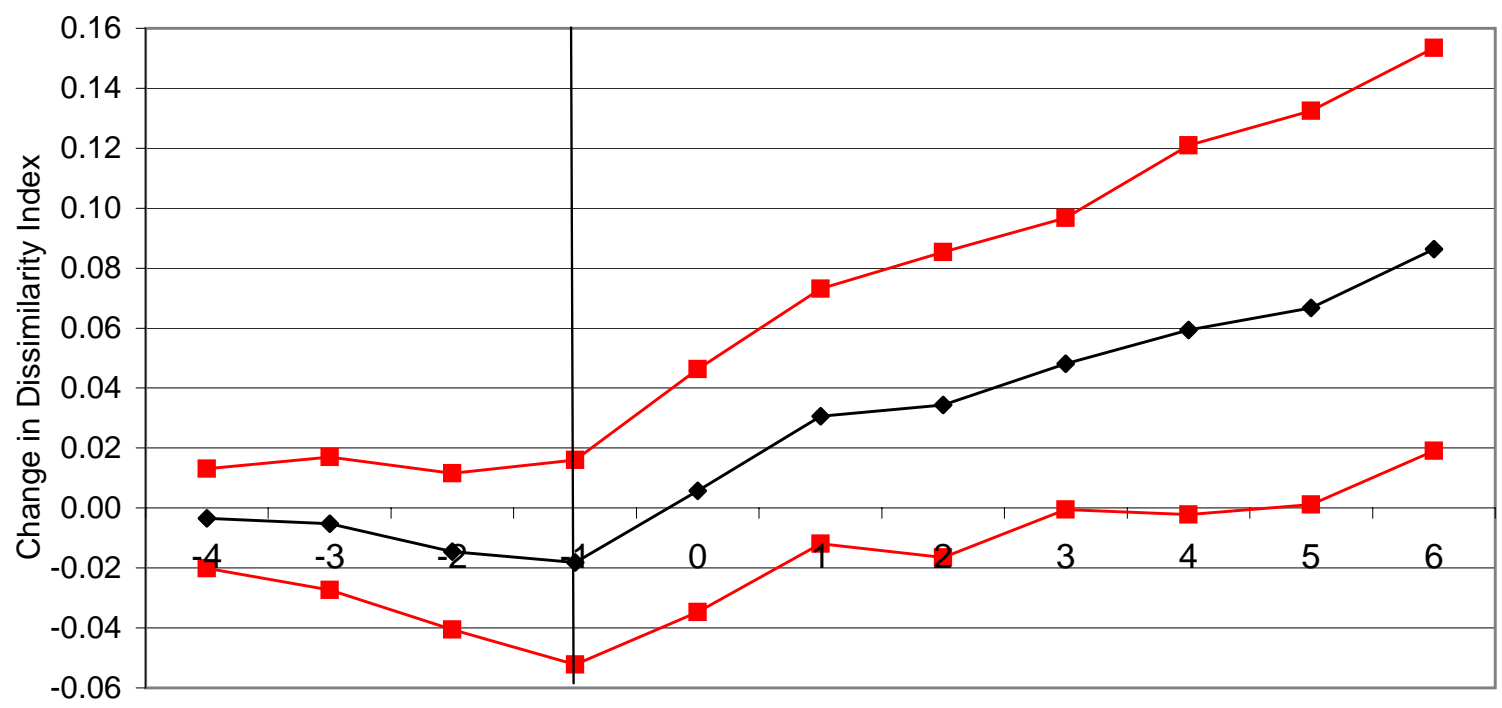

Time Relative to Dismissal ( 0 = Year of Dismissal $)$

\section{$\multimap$ Point Estimate $\rightarrow$ - Upper 95\% Confidence Interval $\rightarrow$ Lower 95\% Confidence Interval}

Note. Panel A plots the coefficients and their 95 percent confidence intervals from the specification presented in Column (2) of Table 2. Panel B plots the coefficients and their 95 percent confidence intervals from the specification presented in Column (6) of Table 2. 
Figure 5: Effect of Dismissal on Exposure Index

Panel A : Full Sample

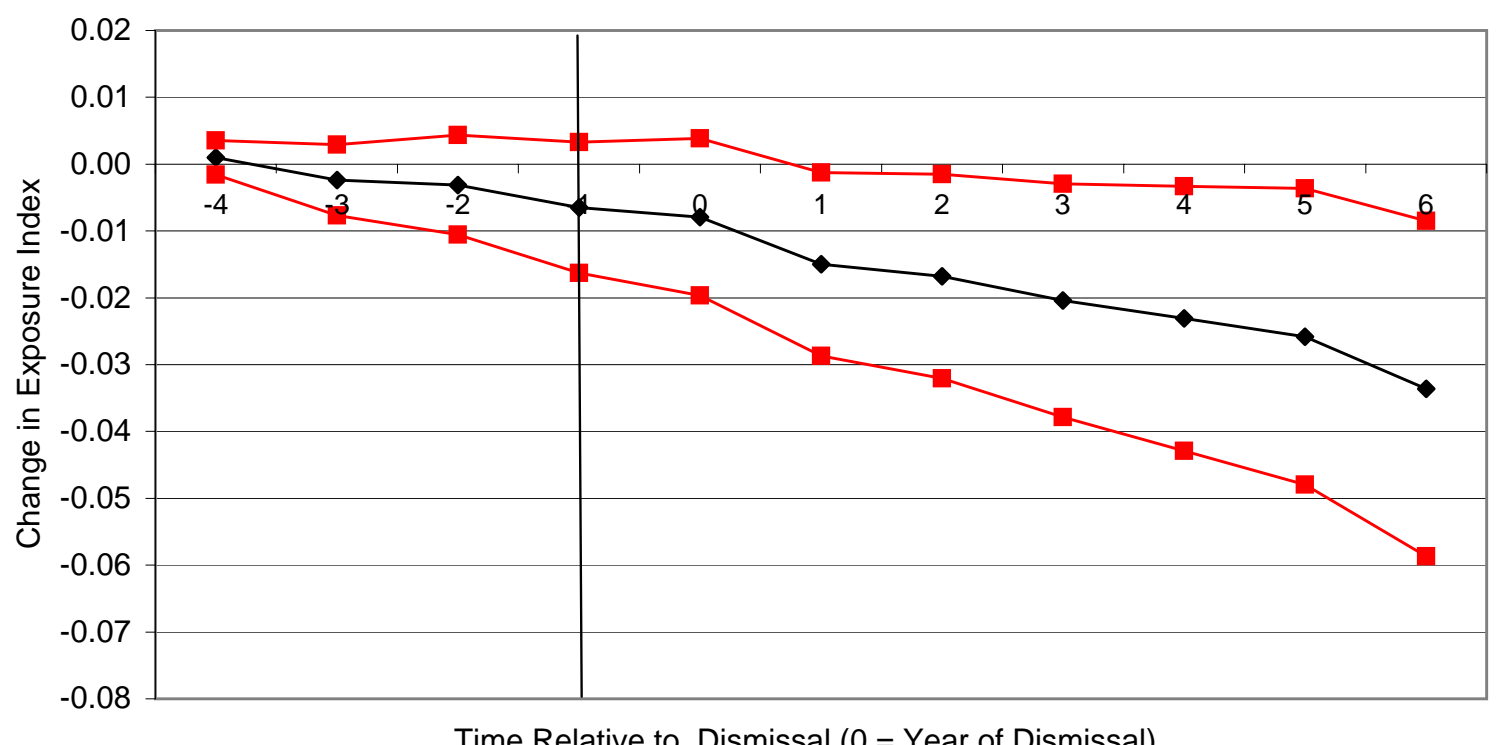

Time Relative to Dismissal $(0=$ Year of Dismissal $)$

Panel B : Balanced Panel

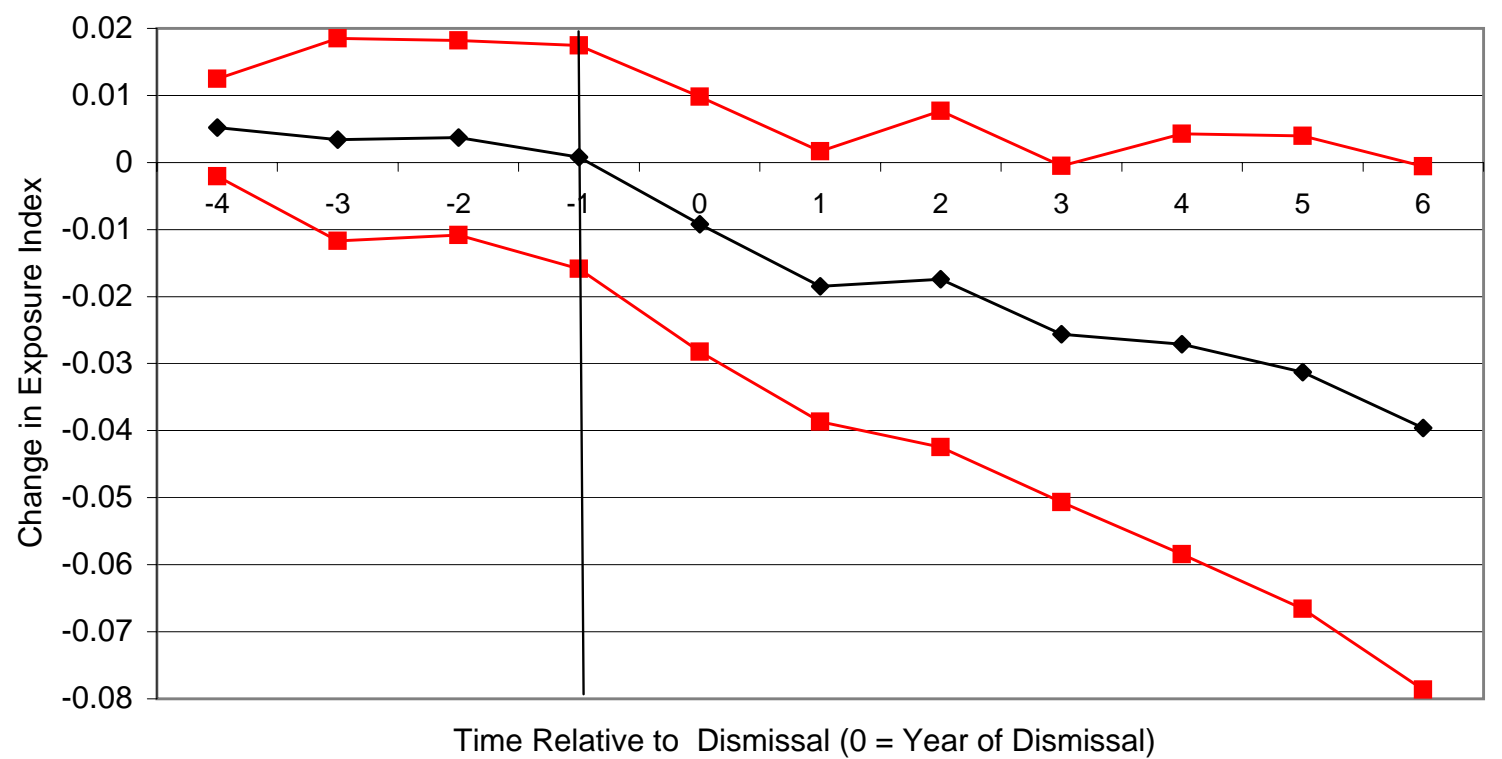

$\rightarrow \rightarrow$ Point Estimate $\rightarrow$ - Upper 95\% Confidence Interval $\rightarrow$ - Lower 95\% Confidence Interval

Note. Panel A plots the coefficients and their 95 percent confidence intervals from the specification presented in Column (2) of Table 4. Panel B plots the coefficients and their 95 percent confidence intervals from the specification presented in Column (6) of Table 4. 
Figure 6: Trends in Status Dropout Rate

Panel A: Black Status Dropout Rate

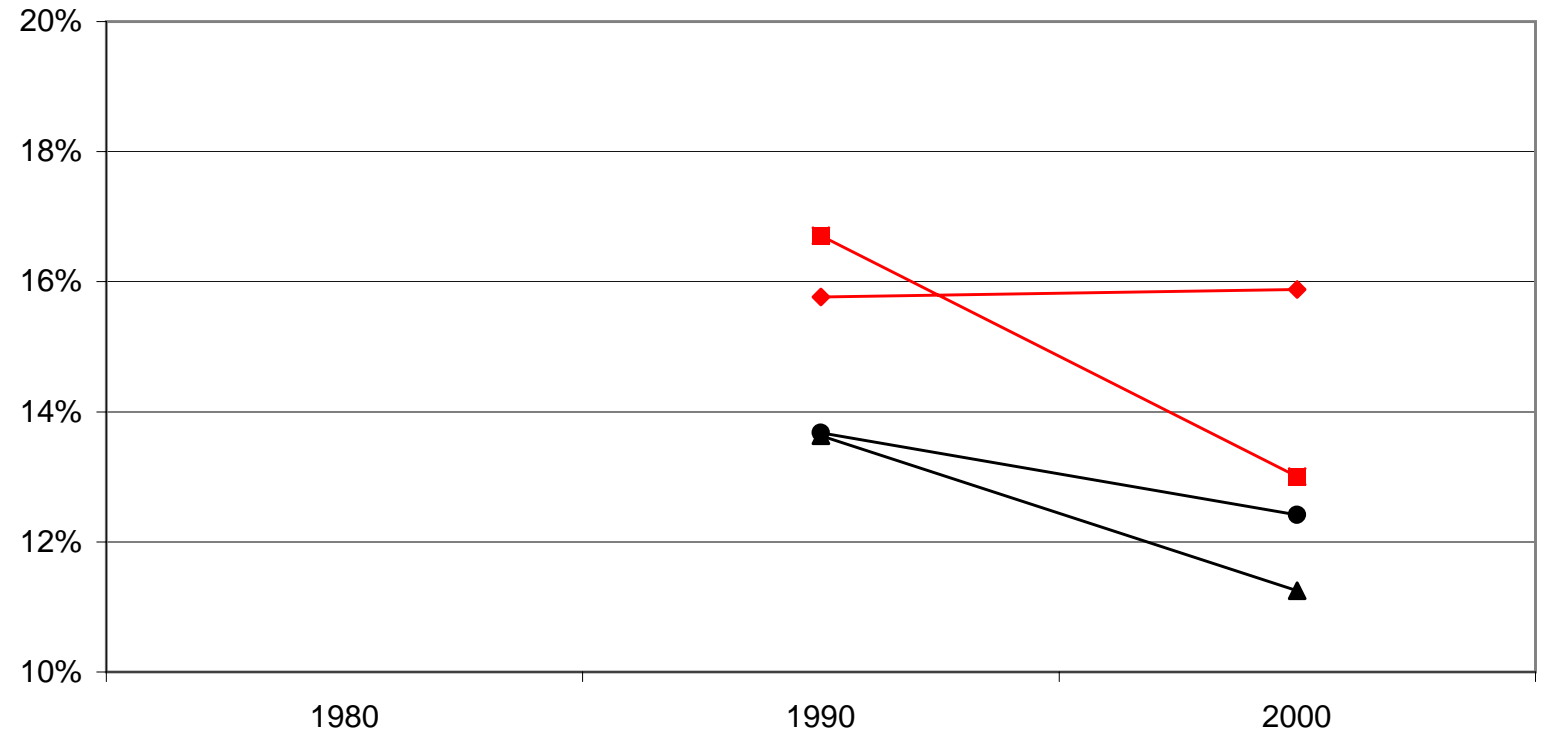

Panel B: Status Dropout Rate for All Races

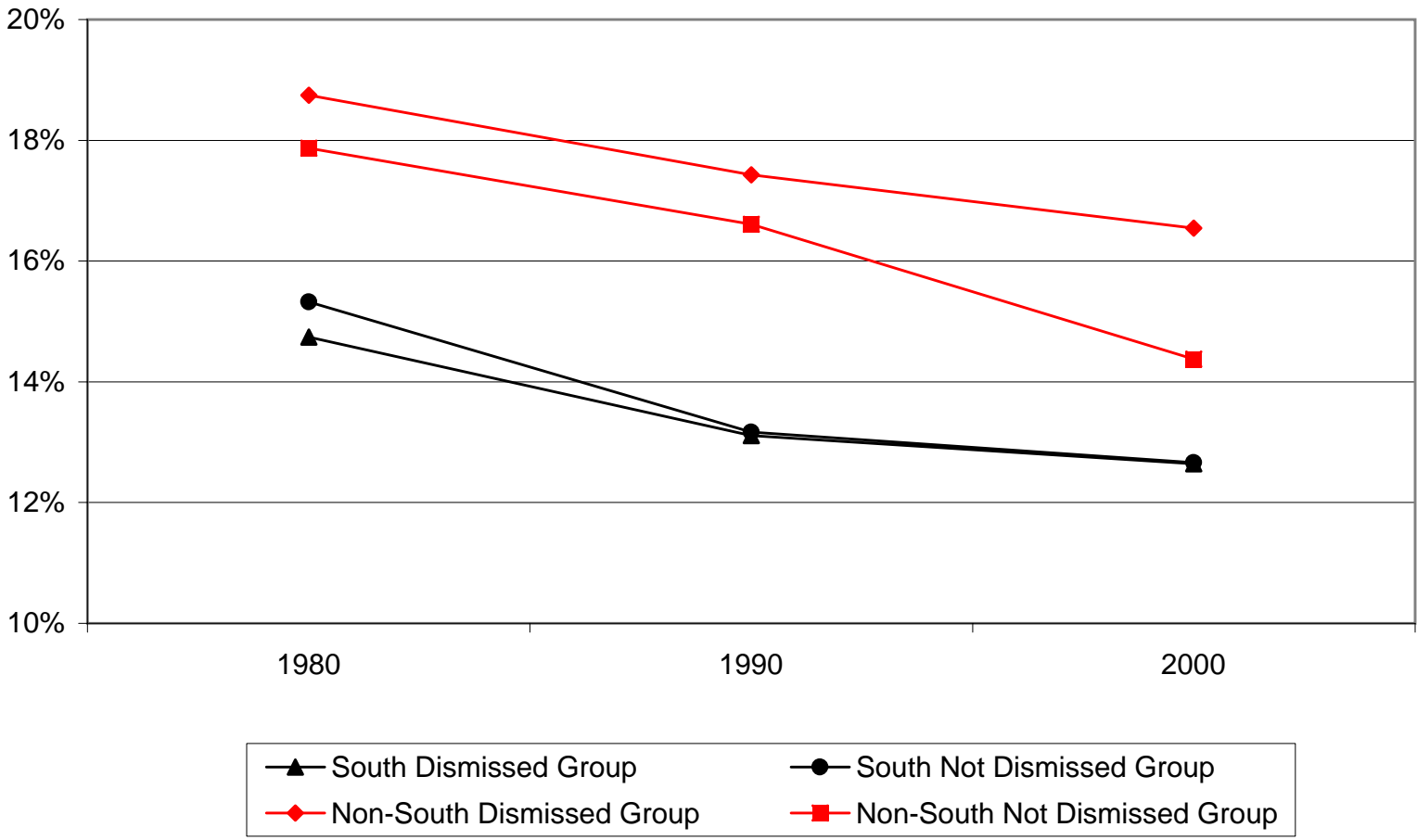

Note. The chart displays the mean school district status dropout rate by non-south treatment and control group and south treatment and control group. The variables are obtained from school district tabulations of the U.S. Census. The treatment group is the set of districts dismissed from 1991 - 1999. The control group is the set of districts not dismissed in this period. The sample is restricted to the set of districts for which nonmissing observations exist for all three years displayed on the chart. The means are weighted by the number of $16-19$ blacks residing in the district. These are the weights used in the regressions appearing on Table 9. The black status dropout rate, displayed in Panel A, is not available for 1980. 
Table 1

1990 School District Characteristics

\begin{tabular}{|c|c|c|c|}
\hline & \multicolumn{2}{|c|}{ Under Court-Order as of 1991} & \multirow{2}{*}{$\begin{array}{l}\text { Not Under } \\
\text { Court-Order } \\
\text { as of } 1991 \\
\end{array}$} \\
\hline & $\begin{array}{l}\text { Dismissed } \\
1991-2002 \\
\end{array}$ & $\begin{array}{c}\text { Not Dismissed } \\
\text { as of } 2002 \\
\end{array}$ & \\
\hline \multicolumn{4}{|c|}{ A. School District Characteristics } \\
\hline Dissimilarity Index & $\begin{array}{c}0.33 \\
(0.14)\end{array}$ & $\begin{array}{c}0.34 \\
(0.19)\end{array}$ & $\begin{array}{c}0.32 \\
(0.17)\end{array}$ \\
\hline Exposure Index & $\begin{array}{c}0.40 \\
(0.16)\end{array}$ & $\begin{array}{c}0.45 \\
(0.22)\end{array}$ & $\begin{array}{c}0.60 \\
(0.29)\end{array}$ \\
\hline Enrollment & $\begin{array}{c}58811 \\
(56235)\end{array}$ & $\begin{array}{c}39641 \\
(85291)\end{array}$ & $\begin{array}{l}20790 \\
(51776)\end{array}$ \\
\hline$\%$ black & $\begin{array}{c}0.39 \\
(0.20)\end{array}$ & $\begin{array}{c}0.36 \\
(0.22)\end{array}$ & $\begin{array}{c}0.16 \\
(0.21)\end{array}$ \\
\hline$\%$ white & $\begin{array}{c}0.47 \\
(0.17)\end{array}$ & $\begin{array}{c}0.52 \\
(0.23)\end{array}$ & $\begin{array}{c}0.64 \\
(0.29)\end{array}$ \\
\hline South Region & $\begin{array}{c}0.63 \\
(0.49)\end{array}$ & $\begin{array}{c}0.65 \\
(0.48)\end{array}$ & $\begin{array}{c}0.29 \\
(0.45)\end{array}$ \\
\hline Serves a Central City & $\begin{array}{c}0.63 \\
(0.49)\end{array}$ & $\begin{array}{c}0.48 \\
(0.50)\end{array}$ & $\begin{array}{c}0.30 \\
(0.46)\end{array}$ \\
\hline \multicolumn{4}{|c|}{ B. School District Community Characteristics } \\
\hline Black Status Dropout Rate & $\begin{array}{l}0.15 \\
(0.04)\end{array}$ & $\begin{array}{c}0.14 \\
(0.05)\end{array}$ & $\begin{array}{c}0.11 \\
(0.12)\end{array}$ \\
\hline Median Household Income* & $\begin{array}{c}40976 \\
(11037)\end{array}$ & $\begin{array}{c}40960 \\
(11845)\end{array}$ & $\begin{array}{c}48839 \\
(16941)\end{array}$ \\
\hline$\%$ Households Below Poverty Line & $\begin{array}{c}0.21 \\
(0.10)\end{array}$ & $\begin{array}{c}0.21 \\
(0.10)\end{array}$ & $\begin{array}{c}0.16 \\
(0.11)\end{array}$ \\
\hline Number of Observations ${ }^{\star *}$ & 35 & 79 & 403 \\
\hline
\end{tabular}


Table 2

Effect of Desegregation Order Dismissal on Dissimilarity Index

\begin{tabular}{|c|c|c|c|c|c|c|c|}
\hline & $(1)$ & $(2)$ & $(3)$ & $(4)$ & $(5)$ & $(6)$ & $(7)$ \\
\hline \multicolumn{8}{|c|}{ Pre-Dismissal } \\
\hline pre(-4) & $\begin{array}{c}0.002 \\
(0.004)\end{array}$ & $\begin{array}{c}0.001 \\
(0.004)\end{array}$ & $\begin{array}{c}0.001 \\
(0.005)\end{array}$ & $\begin{array}{c}0.002 \\
(0.004)\end{array}$ & $\begin{array}{c}0.001 \\
(0.004)\end{array}$ & $\begin{array}{c}-0.004 \\
(0.009)\end{array}$ & $\begin{array}{c}0.000 \\
(0.004)\end{array}$ \\
\hline pre(-3) & $\begin{array}{c}0.002 \\
(0.007)\end{array}$ & $\begin{array}{c}0.000 \\
(0.008)\end{array}$ & $\begin{array}{c}0.002 \\
(0.009)\end{array}$ & $\begin{array}{c}0.007 \\
(0.009)\end{array}$ & $\begin{array}{c}0.000 \\
(0.009)\end{array}$ & $\begin{array}{l}-0.005 \\
(0.011)\end{array}$ & $\begin{array}{c}-0.001 \\
(0.007)\end{array}$ \\
\hline pre(-2) & $\begin{array}{c}0.004 \\
(0.009)\end{array}$ & $\begin{array}{c}0.000 \\
(0.010)\end{array}$ & $\begin{array}{c}0.003 \\
(0.011)\end{array}$ & $\begin{array}{c}0.008 \\
(0.011)\end{array}$ & $\begin{array}{c}0.001 \\
(0.011)\end{array}$ & $\begin{array}{l}-0.015 \\
(0.013)\end{array}$ & $\begin{array}{l}-0.001 \\
(0.009)\end{array}$ \\
\hline pre(-1) & $\begin{array}{c}0.010 \\
(0.011)\end{array}$ & $\begin{array}{c}0.006 \\
(0.012)\end{array}$ & $\begin{array}{c}0.009 \\
(0.012)\end{array}$ & $\begin{array}{c}0.015 \\
(0.012)\end{array}$ & $\begin{array}{c}0.006 \\
(0.014)\end{array}$ & $\begin{array}{l}-0.018 \\
(0.017)\end{array}$ & $\begin{array}{c}0.004 \\
(0.011)\end{array}$ \\
\hline \multicolumn{8}{|c|}{ Post-Dismissal } \\
\hline $\operatorname{post}(0)$ & $\begin{array}{c}0.013 \\
(0.013)\end{array}$ & $\begin{array}{c}0.008 \\
(0.014)\end{array}$ & $\begin{array}{c}0.013 \\
(0.015)\end{array}$ & $\begin{array}{c}0.021 \\
(0.014)\end{array}$ & $\begin{array}{c}0.009 \\
(0.017)\end{array}$ & $\begin{array}{c}0.006 \\
(0.021)\end{array}$ & $\begin{array}{c}0.006 \\
(0.014)\end{array}$ \\
\hline post(1) & $\begin{array}{c}0.030 \\
(0.014)\end{array}$ & $\begin{array}{c}0.026 \\
(0.015)\end{array}$ & $\begin{array}{c}0.032 \\
(0.016)\end{array}$ & $\begin{array}{c}0.038 \\
(0.015)\end{array}$ & $\begin{array}{c}0.029 \\
(0.019)\end{array}$ & $\begin{array}{c}0.031 \\
(0.022)\end{array}$ & $\begin{array}{c}0.019 \\
(0.015)\end{array}$ \\
\hline post(2) & $\begin{array}{c}0.042 \\
(0.016)\end{array}$ & $\begin{array}{c}0.040 \\
(0.018)\end{array}$ & $\begin{array}{c}0.038 \\
(0.017)\end{array}$ & $\begin{array}{c}0.045 \\
(0.017)\end{array}$ & $\begin{array}{c}0.045 \\
(0.023)\end{array}$ & $\begin{array}{c}0.034 \\
(0.026)\end{array}$ & $\begin{array}{c}0.034 \\
(0.018)\end{array}$ \\
\hline post(3) & $\begin{array}{c}0.053 \\
(0.017)\end{array}$ & $\begin{array}{c}0.049 \\
(0.019)\end{array}$ & $\begin{array}{c}0.049 \\
(0.018)\end{array}$ & $\begin{array}{c}0.052 \\
(0.018)\end{array}$ & $\begin{array}{c}0.057 \\
(0.025)\end{array}$ & $\begin{array}{c}0.048 \\
(0.025)\end{array}$ & $\begin{array}{c}0.042 \\
(0.018)\end{array}$ \\
\hline post(4) & $\begin{array}{c}0.064 \\
(0.019)\end{array}$ & $\begin{array}{c}0.060 \\
(0.022)\end{array}$ & $\begin{array}{l}0.056 \\
0.020\end{array}$ & $\begin{array}{l}0.059 \\
0.020\end{array}$ & $\begin{array}{l}0.068 \\
0.028\end{array}$ & $\begin{array}{l}0.059 \\
0.031\end{array}$ & $\begin{array}{l}0.051 \\
0.021\end{array}$ \\
\hline post(5) & $\begin{array}{c}0.067 \\
(0.020)\end{array}$ & $\begin{array}{c}0.062 \\
(0.022)\end{array}$ & $\begin{array}{c}0.061 \\
(0.022)\end{array}$ & $\begin{array}{c}0.063 \\
(0.021)\end{array}$ & $\begin{array}{c}0.072 \\
(0.030)\end{array}$ & $\begin{array}{c}0.067 \\
(0.034)\end{array}$ & $\begin{array}{c}0.053 \\
(0.021)\end{array}$ \\
\hline $\operatorname{post}(>=6)$ & $\begin{array}{c}0.080 \\
(0.022)\end{array}$ & $\begin{array}{c}0.075 \\
(0.024)\end{array}$ & $\begin{array}{c}0.074 \\
(0.023)\end{array}$ & $\begin{array}{c}0.075 \\
(0.024)\end{array}$ & $\begin{array}{c}0.084 \\
(0.034)\end{array}$ & $\begin{array}{c}0.086 \\
(0.034)\end{array}$ & $\begin{array}{c}0.063 \\
(0.023)\end{array}$ \\
\hline Number of Observations & 1712 & 1712 & 1296 & 1712 & 1712 & 710 & 1712 \\
\hline Dep. Var. Mean & 0.363 & 0.363 & 0.392 & 0.363 & 0.363 & 0.338 & 0.328 \\
\hline Dep. Var. S.D. & 0.180 & 0.180 & 0.169 & 0.180 & 0.180 & 0.178 & 0.164 \\
\hline $\begin{array}{l}\text { Dep Var. } 1991 \text { Cross- } \\
\text { Section S.D. }\end{array}$ & 0.179 & 0.179 & 0.165 & 0.179 & 0.179 & 0.183 & 0.165 \\
\hline Index Components & $\begin{array}{l}\text { Black- } \\
\text { White }\end{array}$ & $\begin{array}{l}\text { Black- } \\
\text { White }\end{array}$ & $\begin{array}{l}\text { Black- } \\
\text { White }\end{array}$ & $\begin{array}{l}\text { Black- } \\
\text { White }\end{array}$ & $\begin{array}{l}\text { Black- } \\
\text { White }\end{array}$ & $\begin{array}{l}\text { Black- } \\
\text { White }\end{array}$ & $\begin{array}{l}\text { Nonwhite- } \\
\text { White }\end{array}$ \\
\hline School District Effects & $x$ & $x$ & $\mathrm{X}$ & $x$ & $\mathrm{x}$ & $x$ & $\mathrm{X}$ \\
\hline Year * Census Region & $x$ & $x$ & $x$ & $x$ & $x$ & $x$ & $x$ \\
\hline Year * Base Demographics* & & $x$ & $x$ & $x$ & $x$ & $x$ & $x$ \\
\hline Base Enrollment $>=10,000$ & & & $x$ & & & & \\
\hline Weighted by Base Enrollment & & & & $x$ & & & \\
\hline District Specific Trends & & & & & $x$ & & \\
\hline Balanced Panel & & & & & & $\mathrm{X}$ & \\
\hline
\end{tabular}

Note. Standard errors, clustered by district, are presented in parentheses. The sample is restricted to those districts under court-order in 1991. *Base period demographic characteristics include a central city indicator variable, number of students enrolled, number of students enrolled squared, percent of students who are white and percent of students who are hispanic. 
Table 3

Effect of Desegregation Order Dismissal on Enrollment by Race

\begin{tabular}{|c|c|c|c|}
\hline & \multicolumn{3}{|c|}{ Log Enrollment } \\
\hline & $\begin{array}{c}\text { Black } \\
\text { (1) }\end{array}$ & $\begin{array}{c}\text { Non-White } \\
(2)\end{array}$ & $\begin{array}{c}\text { White } \\
(3)\end{array}$ \\
\hline pre(-4) & $\begin{array}{c}\text { Pre-D } \\
0.002 \\
(0.007)\end{array}$ & $\begin{array}{c}0.005 \\
(0.007)\end{array}$ & $\begin{array}{c}0.008 \\
(0.012)\end{array}$ \\
\hline pre(-3) & $\begin{array}{c}0.005 \\
(0.009)\end{array}$ & $\begin{array}{c}0.009 \\
(0.010)\end{array}$ & $\begin{array}{c}-0.012 \\
(0.015)\end{array}$ \\
\hline pre(-2) & $\begin{array}{c}0.006 \\
(0.011)\end{array}$ & $\begin{array}{c}0.016 \\
(0.013)\end{array}$ & $\begin{array}{c}-0.014 \\
(0.020)\end{array}$ \\
\hline pre(-1) & $\begin{array}{c}0.004 \\
(0.013)\end{array}$ & $\begin{array}{c}0.016 \\
(0.016)\end{array}$ & $\begin{array}{c}-0.026 \\
(0.025)\end{array}$ \\
\hline $\operatorname{post}(0)$ & $\begin{array}{c}\text { Post-L } \\
0.005 \\
(0.016)\end{array}$ & $\begin{array}{c}0.017 \\
(0.019)\end{array}$ & $\begin{array}{l}-0.023 \\
(0.029)\end{array}$ \\
\hline post(1) & $\begin{array}{c}0.007 \\
(0.018)\end{array}$ & $\begin{array}{c}0.017 \\
(0.021)\end{array}$ & $\begin{array}{c}-0.030 \\
(0.036)\end{array}$ \\
\hline post(2) & $\begin{array}{c}0.015 \\
(0.022)\end{array}$ & $\begin{array}{c}0.027 \\
(0.025)\end{array}$ & $\begin{array}{l}-0.016 \\
(0.039)\end{array}$ \\
\hline post(3) & $\begin{array}{c}0.015 \\
(0.024)\end{array}$ & $\begin{array}{c}0.028 \\
(0.027)\end{array}$ & $\begin{array}{l}-0.015 \\
(0.044)\end{array}$ \\
\hline post(4) & $\begin{array}{c}0.008 \\
(0.027)\end{array}$ & $\begin{array}{c}0.021 \\
(0.031)\end{array}$ & $\begin{array}{c}-0.017 \\
(0.051)\end{array}$ \\
\hline post(5) & $\begin{array}{c}0.009 \\
(0.029)\end{array}$ & $\begin{array}{c}0.028 \\
(0.034)\end{array}$ & $\begin{array}{r}-0.010 \\
(0.055)\end{array}$ \\
\hline $\operatorname{post}(>=6)$ & $\begin{array}{c}0.011 \\
(0.034)\end{array}$ & $\begin{array}{c}0.032 \\
(0.036)\end{array}$ & $\begin{array}{r}-0.015 \\
(0.059)\end{array}$ \\
\hline $\mathrm{N}$ & 1712 & 1712 & 1712 \\
\hline Dep. Var. Mean & 8.948 & 9.382 & 9.131 \\
\hline Dep. Var. S.D. & 1.314 & 1.327 & 1.288 \\
\hline Dep Var. 1991 Cross Section S.D. & 1.321 & 1.316 & 1.282 \\
\hline
\end{tabular}

Note. Standard errors, clustered by district, are presented in parentheses. The sample is restricted to those districts under courtorder in 1991. The dependent variable is the log of enrollment for the given race. The specification, similar to that in column (2) of Table 2, includes district fixed effects, year-census region effects and base period characteristics interacted with year indicator variables. Base period demographic characteristics include a central city indicator variable, number of students enrolled and number of students enrolled squared. 
Table 4

Effect of Desegregation Order Dismissal on Exposure Index

\begin{tabular}{|c|c|c|c|c|c|c|c|}
\hline & $(1)$ & $(2)$ & (3) & $(4)$ & $(5)$ & $(6)$ & $(7)$ \\
\hline \multicolumn{8}{|c|}{ Pre-Dismissal } \\
\hline pre(-4) & $\begin{array}{c}0.000 \\
(0.001)\end{array}$ & $\begin{array}{c}0.001 \\
(0.001)\end{array}$ & $\begin{array}{c}0.002 \\
(0.001)\end{array}$ & $\begin{array}{c}0.001 \\
(0.001)\end{array}$ & $\begin{array}{c}0.002 \\
(0.001)\end{array}$ & $\begin{array}{c}0.005 \\
(0.004)\end{array}$ & $\begin{array}{c}0.001 \\
(0.001)\end{array}$ \\
\hline pre(-3) & $\begin{array}{l}-0.003 \\
(0.003)\end{array}$ & $\begin{array}{l}-0.002 \\
(0.003)\end{array}$ & $\begin{array}{l}-0.001 \\
(0.003)\end{array}$ & $\begin{array}{l}-0.003 \\
(0.002)\end{array}$ & $\begin{array}{l}-0.001 \\
(0.003)\end{array}$ & $\begin{array}{c}0.003 \\
(0.008)\end{array}$ & $\begin{array}{l}-0.003 \\
(0.002)\end{array}$ \\
\hline pre(-2) & $\begin{array}{c}-0.004 \\
(0.004)\end{array}$ & $\begin{array}{l}-0.003 \\
(0.004)\end{array}$ & $\begin{array}{c}0.000 \\
(0.004)\end{array}$ & $\begin{array}{l}-0.003 \\
(0.003)\end{array}$ & $\begin{array}{c}-0.001 \\
(0.004)\end{array}$ & $\begin{array}{c}0.004 \\
(0.007)\end{array}$ & $\begin{array}{l}-0.003 \\
(0.004)\end{array}$ \\
\hline pre(-1) & $\begin{array}{l}-0.008 \\
(0.005)\end{array}$ & $\begin{array}{l}-0.007 \\
(0.005)\end{array}$ & $\begin{array}{l}-0.002 \\
(0.005)\end{array}$ & $\begin{array}{l}-0.006 \\
(0.004)\end{array}$ & $\begin{array}{l}-0.003 \\
(0.005)\end{array}$ & $\begin{array}{c}0.001 \\
(0.009)\end{array}$ & $\begin{array}{l}-0.006 \\
(0.005)\end{array}$ \\
\hline \multicolumn{8}{|c|}{ Post-Dismissal } \\
\hline $\operatorname{post}(0)$ & $\begin{array}{l}-0.009 \\
(0.006)\end{array}$ & $\begin{array}{l}-0.008 \\
(0.006)\end{array}$ & $\begin{array}{l}-0.003 \\
(0.006)\end{array}$ & $\begin{array}{c}-0.008 \\
(0.005)\end{array}$ & $\begin{array}{c}-0.004 \\
(0.006)\end{array}$ & $\begin{array}{c}-0.009 \\
(0.010)\end{array}$ & $\begin{array}{c}-0.007 \\
(0.006)\end{array}$ \\
\hline post(1) & $\begin{array}{l}-0.017 \\
(0.007)\end{array}$ & $\begin{array}{l}-0.015 \\
(0.007)\end{array}$ & $\begin{array}{c}-0.008 \\
(0.007)\end{array}$ & $\begin{array}{l}-0.013 \\
(0.006)\end{array}$ & $\begin{array}{l}-0.011 \\
(0.007)\end{array}$ & $\begin{array}{l}-0.019 \\
(0.010)\end{array}$ & $\begin{array}{l}-0.012 \\
(0.007)\end{array}$ \\
\hline post(2) & $\begin{array}{l}-0.019 \\
(0.007)\end{array}$ & $\begin{array}{c}-0.017 \\
(0.008)\end{array}$ & $\begin{array}{c}-0.009 \\
(0.008)\end{array}$ & $\begin{array}{l}-0.015 \\
(0.007)\end{array}$ & $\begin{array}{c}-0.013 \\
(0.008)\end{array}$ & $\begin{array}{c}-0.017 \\
(0.013)\end{array}$ & $\begin{array}{c}-0.014 \\
(0.008)\end{array}$ \\
\hline post(3) & $\begin{array}{l}-0.022 \\
(0.009)\end{array}$ & $\begin{array}{l}-0.020 \\
(0.009)\end{array}$ & $\begin{array}{l}-0.012 \\
(0.008)\end{array}$ & $\begin{array}{l}-0.017 \\
(0.008)\end{array}$ & $\begin{array}{l}-0.016 \\
(0.010)\end{array}$ & $\begin{array}{l}-0.026 \\
(0.013)\end{array}$ & $\begin{array}{l}-0.016 \\
(0.009)\end{array}$ \\
\hline post(4) & $\begin{array}{l}-0.026 \\
(0.010)\end{array}$ & $\begin{array}{l}-0.023 \\
(0.010)\end{array}$ & $\begin{array}{c}-0.013 \\
(0.010)\end{array}$ & $\begin{array}{l}-0.019 \\
(0.009)\end{array}$ & $\begin{array}{c}-0.018 \\
(0.011)\end{array}$ & $\begin{array}{c}-0.027 \\
(0.016)\end{array}$ & $\begin{array}{c}-0.018 \\
(0.010)\end{array}$ \\
\hline post(5) & $\begin{array}{l}-0.028 \\
(0.011)\end{array}$ & $\begin{array}{l}-0.026 \\
(0.011)\end{array}$ & $\begin{array}{l}-0.015 \\
(0.011)\end{array}$ & $\begin{array}{l}-0.020 \\
(0.010)\end{array}$ & $\begin{array}{l}-0.020 \\
(0.012)\end{array}$ & $\begin{array}{c}-0.031 \\
(0.018)\end{array}$ & $\begin{array}{l}-0.021 \\
(0.011)\end{array}$ \\
\hline $\operatorname{post}(>=6)$ & $\begin{array}{l}-0.036 \\
(0.012)\end{array}$ & $\begin{array}{l}-0.034 \\
(0.013)\end{array}$ & $\begin{array}{l}-0.021 \\
(0.012)\end{array}$ & $\begin{array}{c}-0.024 \\
(0.011)\end{array}$ & $\begin{array}{l}-0.026 \\
(0.014)\end{array}$ & $\begin{array}{l}-0.040 \\
(0.020)\end{array}$ & $\begin{array}{l}-0.028 \\
(0.012)\end{array}$ \\
\hline Number of Observations & 1712 & 1712 & 1296 & 1712 & 1712 & 710 & 1712 \\
\hline Dep. Var. Mean & 0.391 & 0.391 & 0.381 & 0.391 & 0.391 & 0.397 & 0.399 \\
\hline Dep. Var. S.D. & 0.215 & 0.215 & 0.208 & 0.215 & 0.215 & 0.211 & 0.215 \\
\hline $\begin{array}{l}\text { Dep Var. } 1991 \text { Cross- } \\
\text { Section S.D. }\end{array}$ & 0.210 & 0.210 & 0.204 & 0.210 & 0.210 & 0.211 & 0.209 \\
\hline Index Components & $\begin{array}{l}\text { Black- } \\
\text { White }\end{array}$ & $\begin{array}{l}\text { Black- } \\
\text { White }\end{array}$ & $\begin{array}{l}\text { Black- } \\
\text { White }\end{array}$ & $\begin{array}{l}\text { Black- } \\
\text { White }\end{array}$ & $\begin{array}{l}\text { Black- } \\
\text { White }\end{array}$ & $\begin{array}{l}\text { Black- } \\
\text { White }\end{array}$ & $\begin{array}{l}\text { Nonwhite- } \\
\text { White }\end{array}$ \\
\hline School District Effects & $x$ & $x$ & $x$ & $x$ & $x$ & $\mathrm{x}$ & $x$ \\
\hline Year * Census Region & $x$ & $x$ & $x$ & $x$ & $x$ & $x$ & $x$ \\
\hline Year * Base Demographics* & & $x$ & $x$ & $x$ & $x$ & $x$ & $x$ \\
\hline Base Enrollment $>=10,000$ & & & $x$ & & & & \\
\hline Weighted by Base Enrollment & & & & $x$ & & & \\
\hline District Specific Trends & & & & & $x$ & & \\
\hline Balanced Panel & & & & & & $x$ & \\
\hline
\end{tabular}

Note. Standard errors, clustered by district, are presented in parentheses. The sample is restricted to those districts under court-order in 1991. *Base period demographic characteristics include a central city indicator variable, number of students enrolled, number of students enrolled squared, percent of students who are white and percent of students who are hispanic. 
Table 5

Effectivness of Court-Ordered Desegregation : Dissimilarity Index

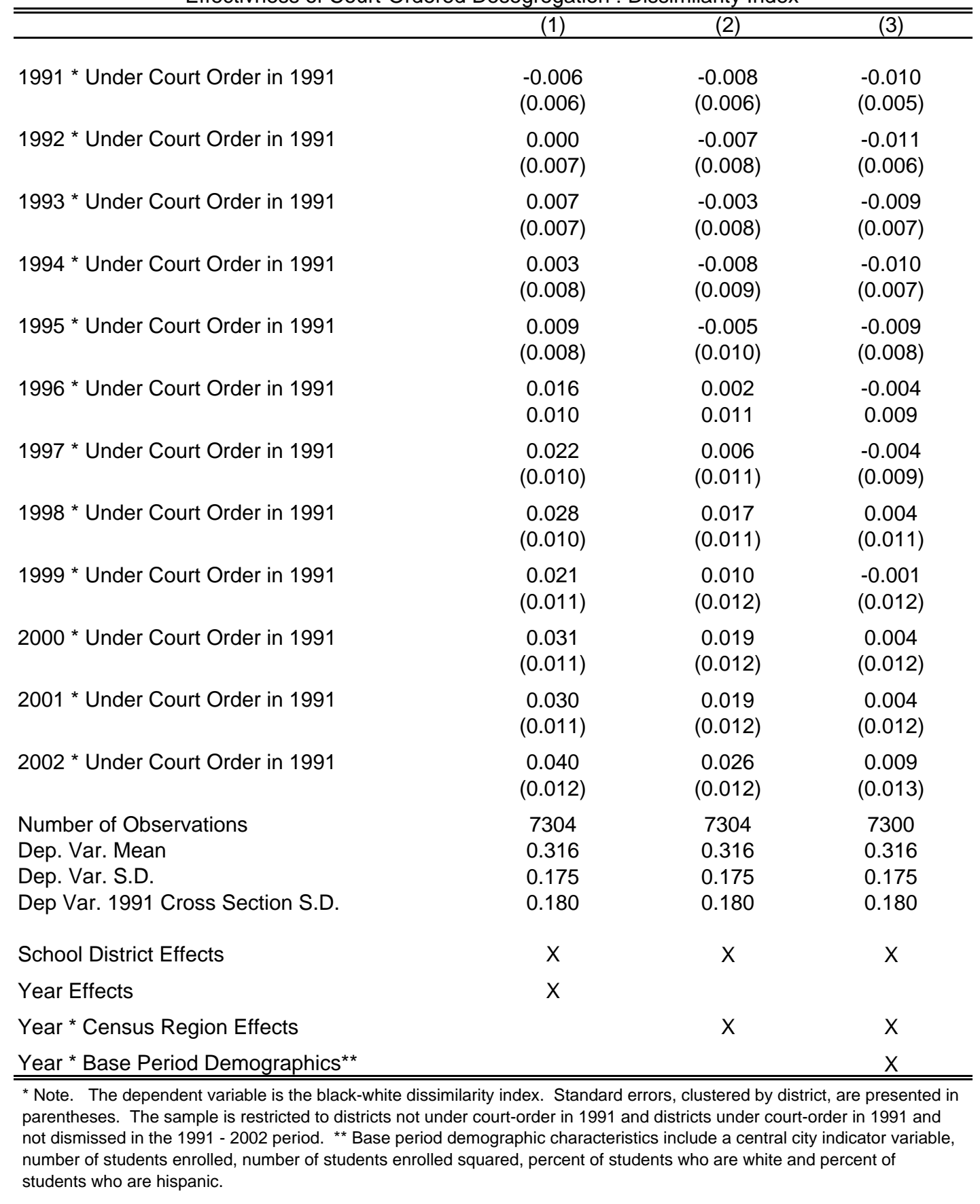


Table 6

1990 School District Community Characteristics of Black Students

\begin{tabular}{|c|c|c|c|c|}
\hline & \multicolumn{2}{|c|}{ Full Sample } & \multicolumn{2}{|c|}{ Non-Southern Districts } \\
\hline & $\begin{array}{c}\text { Dismissed } \\
1991 \text { - } 1999 \\
\end{array}$ & $\begin{array}{c}\text { Not } \\
\text { Dismissed* }\end{array}$ & $\begin{array}{c}\text { Dismissed } \\
1991 \text { - } 1999 \\
\end{array}$ & $\begin{array}{c}\text { Not } \\
\text { Dismissed* }\end{array}$ \\
\hline & \multicolumn{4}{|c|}{ A. Outcome Variables } \\
\hline Black Status Dropout Rate & $\begin{array}{c}0.15 \\
(0.03)\end{array}$ & $\begin{array}{c}0.15 \\
(0.03)\end{array}$ & $\begin{array}{c}0.16 \\
(0.04)\end{array}$ & $\begin{array}{c}0.17 \\
(0.02)\end{array}$ \\
\hline \multirow[t]{2}{*}{ Black Private School Atten. } & $\begin{array}{c}0.07 \\
(0.02)\end{array}$ & $\begin{array}{c}0.08 \\
(0.04)\end{array}$ & $\begin{array}{c}0.07 \\
(0.01)\end{array}$ & $\begin{array}{c}0.11 \\
(0.03)\end{array}$ \\
\hline & \multicolumn{4}{|c|}{ B. Selected Control Variables } \\
\hline South & $\begin{array}{c}0.49 \\
(0.51)\end{array}$ & $\begin{array}{c}0.54 \\
(0.50)\end{array}$ & * & * \\
\hline \% Total HHs in Poverty** & $\begin{array}{c}0.11 \\
(0.06)\end{array}$ & $\begin{array}{c}0.11 \\
(0.05)\end{array}$ & $\begin{array}{c}0.15 \\
(0.05)\end{array}$ & $\begin{array}{c}0.14 \\
(0.03)\end{array}$ \\
\hline HHs Unemploy. Rate ${ }^{\star \star}$ & $\begin{array}{c}0.07 \\
(0.02)\end{array}$ & $\begin{array}{c}0.08 \\
(0.02)\end{array}$ & $\begin{array}{c}0.08 \\
(0.02)\end{array}$ & $\begin{array}{c}0.09 \\
(0.02)\end{array}$ \\
\hline Mother Not High Sch. Grad. & $\begin{array}{c}0.27 \\
(0.09)\end{array}$ & $\begin{array}{c}0.27 \\
(0.07)\end{array}$ & $\begin{array}{c}0.28 \\
(0.08)\end{array}$ & $\begin{array}{c}0.27 \\
(0.05)\end{array}$ \\
\hline Mother College Grad. & $\begin{array}{c}0.12 \\
(0.05)\end{array}$ & $\begin{array}{c}0.12 \\
(0.04)\end{array}$ & $\begin{array}{c}0.09 \\
(0.04)\end{array}$ & $\begin{array}{c}0.12 \\
(0.04)\end{array}$ \\
\hline Black Household Income ${ }^{\star \star \star}$ & $\begin{array}{l}33305 \\
(7349)\end{array}$ & $\begin{array}{l}35925 \\
(8694)\end{array}$ & $\begin{array}{l}30334 \\
(4194)\end{array}$ & $\begin{array}{l}36419 \\
(5728)\end{array}$ \\
\hline Number of Observations & 22 & 99 & 10 & 33 \\
\hline
\end{tabular}


Table 7

Effect of Desegregation Order Dismissal on Black Status Dropout Rate

\begin{tabular}{|c|c|c|c|c|}
\hline & $\overline{(1)}$ & $\overline{(2)}$ & $(3)$ & $(4)$ \\
\hline \multicolumn{5}{|c|}{ A. All Districts; Linear Dismissal Parameterization } \\
\hline Years Since Dismissal * 2000 & $\begin{array}{c}0.0038 \\
(0.0024)\end{array}$ & $\begin{array}{c}0.0035 \\
(0.0026)\end{array}$ & $\begin{array}{c}0.0036 \\
(0.0022)\end{array}$ & $\begin{array}{c}0.0038 \\
(0.0023)\end{array}$ \\
\hline \multicolumn{5}{|c|}{ B. Heterogeneity by Region; Linear Dismissal Parameterization } \\
\hline Years Since Dismissal * 2000 * Non-South & $\begin{array}{c}0.011 \\
(0.002)\end{array}$ & $\begin{array}{c}0.010 \\
(0.002)\end{array}$ & $\begin{array}{c}0.011 \\
(0.002)\end{array}$ & $\begin{array}{c}0.011 \\
(0.002)\end{array}$ \\
\hline Years Since Dismissal * 2000 * South & $\begin{array}{l}-0.003 \\
(0.002)\end{array}$ & $\begin{array}{l}-0.003 \\
(0.002)\end{array}$ & $\begin{array}{l}-0.002 \\
(0.002)\end{array}$ & $\begin{array}{l}-0.002 \\
(0.002)\end{array}$ \\
\hline \multicolumn{5}{|c|}{ C. Heterogeneity by Region; Linear and Indicator Parameterizations } \\
\hline Linear Dismissed * 2000 * Non-South & $\begin{array}{c}0.009 \\
(0.003)\end{array}$ & $\begin{array}{c}0.010 \\
(0.003)\end{array}$ & $\begin{array}{c}0.010 \\
(0.004)\end{array}$ & $\begin{array}{c}0.009 \\
(0.004)\end{array}$ \\
\hline Linear Dismissed * 2000 * South & $\begin{array}{l}-0.001 \\
(0.003)\end{array}$ & $\begin{array}{l}-0.001 \\
(0.003)\end{array}$ & $\begin{array}{l}-0.002 \\
(0.003)\end{array}$ & $\begin{array}{l}-0.002 \\
(0.004)\end{array}$ \\
\hline Indicator Dismissed * 2000 * Non-South & $\begin{array}{c}0.010 \\
(0.023)\end{array}$ & $\begin{array}{c}0.003 \\
(0.021)\end{array}$ & $\begin{array}{c}0.008 \\
(0.023)\end{array}$ & $\begin{array}{c}0.015 \\
(0.024)\end{array}$ \\
\hline Indicator Dismissed * 2000 * South & $\begin{array}{l}-0.006 \\
(0.016)\end{array}$ & $\begin{array}{l}-0.006 \\
(0.017)\end{array}$ & $\begin{array}{l}-0.001 \\
(0.017)\end{array}$ & $\begin{array}{c}0.002 \\
(0.023)\end{array}$ \\
\hline \multicolumn{5}{|c|}{ D. Heterogeneity by Region; Indicator Dismissal Parameterization } \\
\hline Dismissed * 2000 * Non-South & $\begin{array}{c}0.040 \\
(0.018)\end{array}$ & $\begin{array}{c}0.036 \\
(0.016)\end{array}$ & $\begin{array}{c}0.042 \\
(0.018)\end{array}$ & $\begin{array}{c}0.049 \\
(0.017)\end{array}$ \\
\hline Dismissed * 2000 * South & $\begin{array}{l}-0.019 \\
(0.012)\end{array}$ & $\begin{array}{l}-0.019 \\
(0.012)\end{array}$ & $\begin{array}{l}-0.011 \\
(0.010)\end{array}$ & $\begin{array}{l}-0.009 \\
(0.011)\end{array}$ \\
\hline Placebo Dismissed * 2000 * Non-South & $\begin{array}{c}0.023 \\
(0.016)\end{array}$ & $\begin{array}{c}0.018 \\
(0.016)\end{array}$ & $\begin{array}{c}0.017 \\
(0.019)\end{array}$ & $\begin{array}{c}0.024 \\
(0.018)\end{array}$ \\
\hline Placebo Dismissed * 2000 * South & $\begin{array}{l}-0.014 \\
(0.009)\end{array}$ & $\begin{array}{l}-0.013 \\
(0.009)\end{array}$ & $\begin{array}{l}-0.008 \\
(0.011)\end{array}$ & $\begin{array}{l}-0.008 \\
(0.011)\end{array}$ \\
\hline $\begin{array}{l}\text { Observations } \\
\text { (Region, Cent. City) }{ }^{*} 2000 \\
1990 \text { Covariates }^{B} * 2000 \\
\text { Time-Varying Covariates }^{C}\end{array}$ & 242 & $\begin{array}{c}242 \\
x\end{array}$ & $\begin{array}{c}242 \\
X \\
X\end{array}$ & $\begin{array}{l}242 \\
X \\
X \\
X\end{array}$ \\
\hline \multicolumn{5}{|c|}{$\begin{array}{l}\text { Note. Standard errors clustered by district in parentheses. All columns are weighted by cell size. The dependent variable is the school } \\
\text { district mean black status dropout rate for } 16 \text { - } 19 \text { year old. South refers to the South Census region. Column (1) includes an indicator for } \\
\text { the south census region interacted with an indicator for the year } 2000 \text { in panels B, C and D. }{ }^{B} 1990 \text { covariates include both student and } \\
\text { district level variables. The district level covariates, which are measured for all races, are percent receiving public assistance income, the } \\
\text { unemployment rate, percent of households which do not speak English at home, percent of all children who are hispanic, percent of all } \\
\text { children who are white and a quadratic in the total number of children residing in the district. The student level covariates, i.e. means } \\
\text { calculated over the population of black children, include percent of mother's with a high school degree, percent of mothers with a four-year } \\
\text { college degree, percent of children with a parent who is foreign born, percent of children below the poverty line, percent of children born out } \\
\text { of state, and a quadratic in the household income of households with children. }{ }^{C} \text { time-varying covariates are the same as the student-level } \\
\text { covariates listed above. Coefficient estimates for the complete set of covariates available from the author upon request. }\end{array}$} \\
\hline
\end{tabular}


Table 8

Effect of Desegregation Order Dismissal on Black Private School Attendance Rate

\begin{tabular}{|c|c|c|c|c|}
\hline & $(1)$ & $(2)$ & $(3)$ & $(4)$ \\
\hline \multicolumn{5}{|c|}{ A. All Districts; Linear Dismissal Parameterization } \\
\hline Years Since Dismissal * 2000 & $\begin{array}{c}0.0019 \\
(0.0009)\end{array}$ & $\begin{array}{c}0.0017 \\
(0.0007)\end{array}$ & $\begin{array}{c}0.0014 \\
(0.0008)\end{array}$ & $\begin{array}{c}0.0012 \\
(0.0008)\end{array}$ \\
\hline \multicolumn{5}{|c|}{ B. Heterogeneity by Region; Linear Dismissal Parameterization } \\
\hline Years Since Dismissal * 2000 * Non-South & $\begin{array}{c}0.0037 \\
(0.0011)\end{array}$ & $\begin{array}{c}0.0034 \\
(0.0007)\end{array}$ & $\begin{array}{c}0.0026 \\
(0.0012)\end{array}$ & $\begin{array}{c}0.0022 \\
(0.0011)\end{array}$ \\
\hline Years Since Dismissal * 2000 * South & $\begin{array}{l}0.0002 \\
(0.001)\end{array}$ & $\begin{array}{c}0.0002 \\
(0.0008)\end{array}$ & $\begin{array}{c}0.0005 \\
(0.0010)\end{array}$ & $\begin{array}{c}0.0004 \\
(0.0011)\end{array}$ \\
\hline \multicolumn{5}{|c|}{ C. Heterogeneity by Region; Indicator Dismissal Parameterization } \\
\hline Dismissed * 2000 * Non-South & $\begin{array}{c}0.0120 \\
(0.0094)\end{array}$ & $\begin{array}{c}0.0075 \\
(0.0087)\end{array}$ & $\begin{array}{l}-0.0017 \\
(0.0086)\end{array}$ & $\begin{array}{c}-0.0028 \\
(0.0078)\end{array}$ \\
\hline Dismissed * 2000 * South & $\begin{array}{c}0.0007 \\
(0.0052)\end{array}$ & $\begin{array}{c}0.0000 \\
(0.0040)\end{array}$ & $\begin{array}{c}-0.0004 \\
(0.0047)\end{array}$ & $\begin{array}{c}-0.0013 \\
(0.0041)\end{array}$ \\
\hline Placebo Dismissed * 2000 * Non-South & $\begin{array}{c}0.0026 \\
(0.0121)\end{array}$ & $\begin{array}{l}-0.0070 \\
(0.0124)\end{array}$ & $\begin{array}{l}-0.0163 \\
(0.0162)\end{array}$ & $\begin{array}{c}-0.0171 \\
(0.0140)\end{array}$ \\
\hline Placebo Dismissed * 2000 * South & $\begin{array}{c}0.0025 \\
(0.0057)\end{array}$ & $\begin{array}{c}0.0009 \\
(0.0054)\end{array}$ & $\begin{array}{c}0.0003 \\
(0.0051)\end{array}$ & $\begin{array}{c}0.0030 \\
(0.0050)\end{array}$ \\
\hline $\begin{array}{l}\text { Observations } \\
\text { (Region, Cent. City) }{ }^{*} 2000 \\
1990 \text { Covariates }^{B} * 2000 \\
\text { Time-Varying Covariates }^{C}\end{array}$ & 242 & $\begin{array}{c}242 \\
x\end{array}$ & $\begin{array}{l}242 \\
X \\
X\end{array}$ & $\begin{array}{l}242 \\
X \\
x \\
x\end{array}$ \\
\hline
\end{tabular}

Note. Standard errors clustered by district in parentheses. All columns are weighted by cell size. The dependent variable is the school district mean black private school attendance rate. South refers to the South Census region. Column (1) includes an indicator for the soutr census region interacted with an indicator for the year 2000 in panels B and C. ${ }^{B} 1990$ covariates include both student and district level variables. The district level covariates, which are measured for all races, are percent receiving public assistance income, the unemployment rate, percent of households which do not speak English at home, percent of all children who are hispanic, percent of all children who are white and a quadratic in the total number of children residing in the district. The student level covariates, i.e. means calculated over the population of black children, include percent of mother's with a high school degree, percent of mothers with a four-year college degree, percent of children with a parent who is foreign born, percent of children below the poverty line, percent of children born out of state, and a quadratic in the household income of households with children. ${ }^{\mathrm{c}}$ time-varying covariates are the same as the student-level covariates listed above. Coefficient estimates for the complete set of covariates available from the author upon request. 
Table 9

Effect of Desegregation Order Dismissal on White Dropout Rate and Private School Attendance

\begin{tabular}{|c|c|c|c|c|}
\hline & $(1)$ & $(2)$ & $(3)$ & $(4)$ \\
\hline \multicolumn{5}{|c|}{ A. White Status Dropout Rate } \\
\hline Years Since Dismissal * 2000 & $\begin{array}{l}-0.0009 \\
(0.0014)\end{array}$ & $\begin{array}{l}-0.0009 \\
(0.0014)\end{array}$ & $\begin{array}{l}-0.0006 \\
(0.0013)\end{array}$ & $\begin{array}{l}-0.0002 \\
(0.0013)\end{array}$ \\
\hline \multicolumn{5}{|c|}{ B. White Status Dropout Rate - Heterogeniety by Region } \\
\hline Years Since Dismissal * 2000 * Non-South & $\begin{array}{c}0.0011 \\
(0.0013)\end{array}$ & $\begin{array}{c}0.0010 \\
(0.0013)\end{array}$ & $\begin{array}{c}0.0011 \\
(0.0015)\end{array}$ & $\begin{array}{c}0.0013 \\
(0.0013)\end{array}$ \\
\hline Years Since Dismissal * 2000 * South & $\begin{array}{l}-0.0024 \\
(0.0016)\end{array}$ & $\begin{array}{c}-0.0024 \\
(0.0017)\end{array}$ & $\begin{array}{l}-0.0018 \\
(0.0014)\end{array}$ & $\begin{array}{l}-0.0011 \\
(0.0015)\end{array}$ \\
\hline \multicolumn{5}{|c|}{ C. White Private School Attendance } \\
\hline Years Since Dismissal * 2000 & $\begin{array}{c}0.0017 \\
(0.0022)\end{array}$ & $\begin{array}{c}0.0016 \\
(0.0026)\end{array}$ & $\begin{array}{c}-0.0014 \\
(0.0023)\end{array}$ & $\begin{array}{l}-0.0023 \\
(0.0019)\end{array}$ \\
\hline \multicolumn{5}{|c|}{ D. White Private School Attendance - Heterogeniety by Region } \\
\hline Years Since Dismissal * 2000 * Non-South & $\begin{array}{c}0.0068 \\
(0.0018)\end{array}$ & $\begin{array}{c}0.0065 \\
(0.0016)\end{array}$ & $\begin{array}{c}0.0027 \\
(0.0025)\end{array}$ & $\begin{array}{c}0.0001 \\
(0.0024)\end{array}$ \\
\hline Years Since Dismissal * 2000 * South & $\begin{array}{l}-0.0010 \\
(0.0030)\end{array}$ & $\begin{array}{l}-0.0016 \\
(0.0031)\end{array}$ & $\begin{array}{c}-0.0038 \\
(0.0027)\end{array}$ & $\begin{array}{l}-0.0035 \\
(0.0025)\end{array}$ \\
\hline $\begin{array}{l}\text { Observations } \\
\text { (Region, Cent. City) }{ }^{*} 2000 \\
1990 \text { Covariates }^{B} * 2000 \\
\text { Time-Varying Covariates }^{C}\end{array}$ & 242 & $\begin{array}{c}242 \\
x\end{array}$ & $\begin{array}{c}242 \\
X \\
X\end{array}$ & $\begin{array}{c}242 \\
X\end{array}$ \\
\hline \multicolumn{5}{|c|}{$\begin{array}{l}\text { Note. Standard errors clustered by district in parentheses. All columns are weighted by cell size. The dependent variable is } \\
\text { as labeled in the panel headings. South refers to the South Census region. Column (1) includes an indicator for the south } \\
\text { census region interacted with an indicator for the year } 2000 \text { in panels B and D. }{ }^{B} 1990 \text { covariates include both student and } \\
\text { district level variables. The district level covariates, which are measured for all races, are percent receiving public assistance } \\
\text { income, the unemployment rate, percent of households which do not speak English at home, percent of all children who are } \\
\text { hispanic, percent of all children who are white and a quadratic in the total number of children residing in the district. The studen } \\
\text { level covariates, i.e. means calculated over the population of white children, include percent of mother's with a high school } \\
\text { degree, percent of mothers with a four-year college degree, percent of children with a parent who is foreign born, percent of } \\
\text { children below the poverty line, percent of children born out of state, and a quadratic in the household income of households } \\
\text { with children. C } \text { time-varying covariates are the same as the student-level covariates listed above. Coefficient estimates for the }_{\text {complete set of covariates available from the author upon request. }}\end{array}$} \\
\hline
\end{tabular}


Table 10

Effect of Desegregation Order Dismissal on Migration

\begin{tabular}{|c|c|c|c|c|c|c|c|c|c|c|}
\hline & \multicolumn{2}{|c|}{ log 16-19 year olds } & \multicolumn{2}{|c|}{ "Mean Household Income } & \multicolumn{2}{|c|}{ "Mother High School } & \multicolumn{2}{|c|}{ Mother College } & \multicolumn{2}{|c|}{ Percent in Poverty } \\
\hline & $(1)$ & $(2)$ & $(3)$ & $(4)$ & $(5)$ & $(6)$ & $(7)$ & $(8)$ & $(9)$ & $(10)$ \\
\hline \multicolumn{11}{|c|}{ A. Black } \\
\hline Non-South Linear Dis. & $\begin{array}{l}0.0169 \\
(0.006)\end{array}$ & $\begin{array}{c}0.0046 \\
(0.0058)\end{array}$ & $\begin{array}{c}185.7 \\
(195.2)\end{array}$ & $\begin{array}{c}81.8 \\
(142.1)\end{array}$ & $\begin{array}{c}0.0006 \\
(0.0023)\end{array}$ & $\begin{array}{c}0.0018 \\
(0.0024)\end{array}$ & $\begin{array}{c}0.0012 \\
(0.0021)\end{array}$ & $\begin{array}{c}0.0004 \\
(0.0011)\end{array}$ & $\begin{array}{l}-0.0060 \\
(0.0042)\end{array}$ & $\begin{array}{l}-0.0033 \\
(0.0039)\end{array}$ \\
\hline South Linear Dis. & $\begin{array}{l}0.0323 \\
(0.024)\end{array}$ & $\begin{array}{c}0.0277 \\
(0.0161)\end{array}$ & $\begin{array}{c}100.2 \\
(203.1)\end{array}$ & $\begin{array}{c}52.0 \\
(195.1)\end{array}$ & $\begin{array}{c}0.0009 \\
(0.0023)\end{array}$ & $\begin{array}{c}0.0008 \\
(0.0024)\end{array}$ & $\begin{array}{c}0.0001 \\
(0.0021)\end{array}$ & $\begin{array}{c}-0.0008 \\
(0.0011)\end{array}$ & $\begin{array}{c}0.0016 \\
(0.0042)\end{array}$ & $\begin{array}{r}0.0010 \\
(0.0039)\end{array}$ \\
\hline \multicolumn{11}{|c|}{ B. White } \\
\hline Non-South Linear Dis. & $\begin{array}{l}-0.0037 \\
(0.0070)\end{array}$ & $\begin{array}{c}-0.0057 \\
(0.0090)\end{array}$ & $\begin{array}{c}475.9 \\
(496.7)\end{array}$ & $\begin{array}{c}519.5 \\
(345.0)\end{array}$ & $\begin{array}{c}-0.0001 \\
(0.0021)\end{array}$ & $\begin{array}{c}-0.0005 \\
(0.0014)\end{array}$ & $\begin{array}{c}0.0065 \\
(0.0018)\end{array}$ & $\begin{array}{c}0.0053 \\
(0.0014)\end{array}$ & $\begin{array}{l}-0.0035 \\
(0.0018)\end{array}$ & $\begin{array}{c}-0.0032 \\
(0.0011)\end{array}$ \\
\hline South Linear Dis. & $\begin{array}{l}-0.0109 \\
(0.0128)\end{array}$ & $\begin{array}{l}-0.0045 \\
(0.0094)\end{array}$ & $\begin{array}{l}-380.3 \\
(349.7)\end{array}$ & $\begin{array}{l}-624.9 \\
(421.9)\end{array}$ & $\begin{array}{c}0.0013 \\
(0.0015)\end{array}$ & $\begin{array}{c}0.0014 \\
(0.0015)\end{array}$ & $\begin{array}{c}0.0024 \\
(0.0028)\end{array}$ & $\begin{array}{c}0.0002 \\
(0.0023)\end{array}$ & $\begin{array}{c}0.0017 \\
(0.0010)\end{array}$ & $\begin{array}{c}0.0012 \\
(0.0009)\end{array}$ \\
\hline $\begin{array}{l}\text { Observations } \\
\text { (Region, Cent. City) * } 2000 \\
1990 \text { Covariates }^{B} * 2000\end{array}$ & 242 & $\begin{array}{c}242 \\
X \\
X \\
\end{array}$ & 242 & $\begin{array}{c}242 \\
X \\
X \\
\end{array}$ & 242 & $\begin{array}{c}242 \\
X \\
X \\
\end{array}$ & 242 & $\begin{array}{c}242 \\
X \\
X \\
\end{array}$ & 242 & $\begin{array}{c}242 \\
X \\
X \\
\end{array}$ \\
\hline
\end{tabular}

Note. Standard errors clustered by district in parentheses. All columns are weighted by the number of $16-19$ year olds of the relevant race (see panel headings). The dependent variable is as labeled in the column header. Mean household income refers to households with children of the relevant race (see panel heading). Mother high school and mother college refer to the percent of children with mothers who have a high school degree (but not a college degree) and the percent which have a college degree. Columns (1), (3), (5), (7) and (9) include an indicator for the south census region interacted with an indicator for the year 2000. ${ }^{\mathrm{B}} 1990$ covariates include only district level variables. The district level covariates, which are measured for all races, are percent receiving public assistance income, the unemployment rate, percent of households which do not speak English at home, percent of all children who are hispanic, percent of all children who are white and a quadratic in the total number of children residing in the district. 


\begin{tabular}{|c|c|c|c|}
\hline \multicolumn{4}{|c|}{ Appendix Table 1} \\
\hline Districts in Rossell and Armor Sample and $U$ & rt-Orde & segregation & in 1991 \\
\hline & & Dissmissal & Base Period \\
\hline District Name & State & Date & Enrollment \\
\hline AUTAUGA COUNTY SCH DIST & $\overline{\mathrm{AL}}$ & & 6920 \\
\hline BIBB COUNTY SCH DIST & $\mathrm{AL}$ & & 3571 \\
\hline CALHOUN COUNTY SCH DIST & $\mathrm{AL}$ & & 11105 \\
\hline DOTHAN CITY SCH DIST & $\mathrm{AL}$ & & 10028 \\
\hline HUNTSVILLE CITY SCH DIST & $\mathrm{AL}$ & & 24987 \\
\hline JACKSON COUNTY SCH DIST & $\mathrm{AL}$ & & 6720 \\
\hline JEFFERSON COUNTY SCH DIST & $\mathrm{AL}$ & & 41143 \\
\hline MOBILE COUNTY SCH DIST & $\mathrm{AL}$ & 97 & 67841 \\
\hline MONTGOMERY COUNTY SCH DIST & $\mathrm{AL}$ & & 36010 \\
\hline SAINT CLAIR COUNTY SCH DIST & $\mathrm{AL}$ & & 5638 \\
\hline WILCOX COUNTY SCH DIST & $\mathrm{AL}$ & & 2939 \\
\hline PHOENIX UNION HIGH SCHOOL DISTRICT & $A Z$ & & 21117 \\
\hline FORREST CITY & AR & & 5621 \\
\hline LITTLE ROCK & AR & 102 & 26854 \\
\hline N LITTLE ROCK & AR & & 9725 \\
\hline PULASKI CO SPECIAL & AR & & 22280 \\
\hline LOS ANGELES UNIFIED & CA & & 589311 \\
\hline OAKLAND UNIFIED & CA & & 51298 \\
\hline SAN BERNARDINO CITY UNIFIED & CA & & 35033 \\
\hline SAN DIEGO CITY UNIFIED & CA & 98 & 116557 \\
\hline SAN FRANCISCO UNIFIED & CA & & 63881 \\
\hline SAN JOSE UNIFIED & CA & 98 & 29333 \\
\hline STOCKTON CITY UNIFIED & CA & & 31051 \\
\hline DENVER COUNTY & $\mathrm{CO}$ & 95 & 59439 \\
\hline BRIDGEPORT SCHOOL DISTRICT & CT & & 19416 \\
\hline WATERBURY SCHOOL DISTRICT & CT & & 13298 \\
\hline CHRISTINA SCHOOL DISTRICT & $\mathrm{DE}$ & 96 & 16438 \\
\hline RED CLAY CONSOLIDATED SCHOOL DISTRICT & $\mathrm{DE}$ & 96 & 14189 \\
\hline BAY COUNTY SCHOOL DISTRICT & $\mathrm{FL}$ & & 21541 \\
\hline BROWARD COUNTY SCHOOL DISTRICT & $\mathrm{FL}$ & 96 & 137366 \\
\hline DADE COUNTY SCHOOL DISTRICT & $\mathrm{FL}$ & 101 & 253323 \\
\hline DUVAL COUNTY SCHOOL DISTRICT & FL & 101 & 105049 \\
\hline ESCAMBIA COUNTY SCHOOL DISTRICT & $\mathrm{FL}$ & & 42066 \\
\hline HILLSBOROUGH COUNTY SCHOOL DISTRICT & $\mathrm{FL}$ & 101 & 118031 \\
\hline JACKSON COUNTY SCHOOL DISTRICT & $\mathrm{FL}$ & & 7565 \\
\hline LEE COUNTY SCHOOL DISTRICT & FL & 103 & 37708 \\
\hline MARION COUNTY SCHOOL DISTRICT & $\mathrm{FL}$ & & 26433 \\
\hline ORANGE COUNTY SCHOOL DISTRICT & $\mathrm{FL}$ & & 88878 \\
\hline PINELLAS COUNTY SCHOOL DISTRICT & FL & 101 & 88866 \\
\hline POLK COUNTY SCHOOL DISTRICT & $\mathrm{FL}$ & 100 & 61244 \\
\hline SEMINOLE COUNTY SCHOOL DISTRICT & $\mathrm{FL}$ & & 43511 \\
\hline ST LUCIE COUNTY SCHOOL DISTRICT & $\mathrm{FL}$ & 97 & 18260 \\
\hline BIBB COUNTY & GA & & 25158 \\
\hline CHATHAM COUNTY & GA & 94 & 35358 \\
\hline DECATUR COUNTY & GA & & 5810 \\
\hline DEKALB COUNTY & GA & 96 & 81468 \\
\hline DOUGHERTY COUNTY & GA & & 18760 \\
\hline FULTON COUNTY & GA & 103 & 50190 \\
\hline LOWNDES COUNTY & GA & & 7982 \\
\hline MUSCOGEE COUNTY & GA & 97 & 31984 \\
\hline CITY OF CHICAGO SCHOOL DIST 299 & $\mathrm{IL}$ & & 419537 \\
\hline JOLIET PUBLIC SCH DIST 86 & $\mathrm{IL}$ & & 8823 \\
\hline FORT WAYNE COMMUNITY SCHOOLS & $\mathrm{IN}$ & & 32405 \\
\hline INDIANAPOLIS PUBLIC SCHOOLS & IN & 98 & 50496 \\
\hline
\end{tabular}




\begin{tabular}{|c|c|c|c|}
\hline M S D DECATUR TOWNSHIP & IN & & 5146 \\
\hline M S D WAYNE TOWNSHIP & IN & & 12066 \\
\hline SCHOOL CITY OF HAMMOND & IN & & 13737 \\
\hline KANSAS CITY & KS & 97 & 22897 \\
\hline TOPEKA PUBLIC SCHOOLS & KS & 99 & 14783 \\
\hline FAYETTE CO & KY & & 31191 \\
\hline JEFFERSON CO & KY & 100 & 93198 \\
\hline CADDO PARISH SCHOOL BOARD & LA & & 52309 \\
\hline CITY OF MONROE SCHOOL BOARD & LA & & 10922 \\
\hline EAST BATON ROUGE PARISH SCHOOL BOARD & LA & 102 & 60279 \\
\hline EVANGELINE PARISH SCHOOL BOARD & LA & & 6907 \\
\hline JEFFERSON PARISH SCHOOL BOARD & LA & & 57663 \\
\hline LAFAYETTE PARISH SCHOOL BOARD & LA & & 28392 \\
\hline OUACHITA PARISH SCHOOL BOARD & LA & & 17523 \\
\hline POINTE COUPEE PARISH SCHOOL BOARD & LA & & 3868 \\
\hline RAPIDES PARISH SCHOOL BOARD & LA & 102 & 24404 \\
\hline SAINT LANDRY PARISH SCHOOL BOARD & LA & & 17379 \\
\hline SAINT TAMMANY PARISH SCHOOL BOARD & LA & & 28055 \\
\hline WEST FELICIANA PARISH SCHOOL BOARD & LA & & 2050 \\
\hline PRINCE GEORGES COUNTY PUB SCHS & MD & 102 & 104661 \\
\hline HOLYOKE & MA & & 6732 \\
\hline BENTON HARBOR AREA SCHOOLS & MI & 102 & 7129 \\
\hline FLINT CITY SCHOOL DISTRICT & MI & 102 & 30202 \\
\hline GRAND RAPIDS PUBLIC SCHOOLS & MI & & 25225 \\
\hline KALAMAZOO PUBLIC SCHOOL DISTRICT & MI & & 12810 \\
\hline LANSING PUBLIC SCHOOL DISTRICT & MI & & 22477 \\
\hline CARROLL COUNTY SCHOOL DIST & MS & & 1218 \\
\hline CLEVELAND SCHOOL DIST & MS & & 4726 \\
\hline HATTIESBURG PUBLIC SCHOOL DIST & MS & 97 & 5789 \\
\hline NATCHEZ-ADAMS SCHOOL DIST & MS & & 6841 \\
\hline RANKIN CO SCHOOL DIST & MS & & 12126 \\
\hline VICKSBURG WARREN SCHOOL DIST & MS & & 10380 \\
\hline KANSAS CITY 33 & $\mathrm{MO}$ & 103 & 35227 \\
\hline ROCKWOOD R-VI & $\mathrm{MO}$ & & 16484 \\
\hline ST LOUIS CITY & MO & 99 & 42088 \\
\hline OMAHA PUBLIC SCHOOLS & $\mathrm{NE}$ & & 41416 \\
\hline MONTCLAIR TOWN & $\mathrm{NJ}$ & & 5141 \\
\hline UNION TWP & $\mathrm{NJ}$ & & 5971 \\
\hline BUFFALO CITY SD & NY & 95 & 46251 \\
\hline NEW ROCHELLE CITY SD & NY & & 7633 \\
\hline SYRACUSE CITY SD & NY & & 20972 \\
\hline UTICA CITY SD & NY & & 8317 \\
\hline YONKERS CITY SD & NY & 102 & 17744 \\
\hline HIGH POINT CITY & NC & & 8160 \\
\hline CHARLOTTE-MECKLENBURG SCHOOLS & NC & 101 & 74149 \\
\hline FORSYTH COUNTY SCHOOLS & NC & & 38311 \\
\hline HALIFAX COUNTY SCHOOLS & NC & & 6608 \\
\hline VANCE COUNTY SCHOOLS & NC & & 7561 \\
\hline CINCINNATI CITY SD & $\mathrm{OH}$ & 91 & 51819 \\
\hline CLEVELAND MUNICIPAL SD & $\mathrm{OH}$ & 99 & 71743 \\
\hline DAYTON CITY SD & $\mathrm{OH}$ & 102 & 28768 \\
\hline LORAIN CITY SD & $\mathrm{OH}$ & & 12212 \\
\hline OKLAHOMA CITY & OK & 91 & 39149 \\
\hline ERIE CITY SD & PA & & 12485 \\
\hline PHILADELPHIA CITY SD & PA & & 194698 \\
\hline SUMTER COUNTY SCHOOL DISTRICT 02 & SC & & 8661 \\
\hline CHATTANOOGA CITY SCHOOLS & TN & & 22872 \\
\hline MEMPHIS CITY SCHOOL DISTRICT & $\mathrm{TN}$ & & 105856 \\
\hline
\end{tabular}




\begin{tabular}{|c|c|c|c|}
\hline NASHVILLE-DAVIDSON COUNTY SD & $\mathrm{TN}$ & 98 & 66973 \\
\hline SHELBY COUNTY SCHOOL DISTRICT & TN & & 33683 \\
\hline ALDINE ISD & TX & 102 & 37657 \\
\hline CORPUS CHRISTI ISD & TX & 97 & 41850 \\
\hline CROSBY ISD & TX & & 3246 \\
\hline DALLAS ISD & TX & 103 & 130885 \\
\hline ECTOR COUNTY ISD & TX & & 25770 \\
\hline GALENA PARK ISD & TX & & 13938 \\
\hline GARLAND ISD & TX & & 34603 \\
\hline RICHARDSON ISD & TX & & 32080 \\
\hline TEMPLE ISD & TX & 100 & 8110 \\
\hline WICHITA FALLS ISD & TX & 100 & 15055 \\
\hline MILWAUKEE & WI & & 91648 \\
\hline \multicolumn{4}{|c|}{ Note. Base period enrollment is total student enrollment in the first year the district appears in the sample } \\
\hline \multicolumn{4}{|c|}{\begin{tabular}{|l|l|l|} 
See Appendix B. & & \\
\end{tabular}} \\
\hline & & & \\
\hline
\end{tabular}


Appendix Table 2

Effect of Desegregation Order Dismissal on Segregation Indices; Heterogeneity by Region

\begin{tabular}{|c|c|c|c|c|}
\hline & \multicolumn{2}{|c|}{ Dissimilarity Index } & \multicolumn{2}{|c|}{ Exposure Index } \\
\hline & $\begin{array}{l}\text { Main Effect } \\
\text { (1) }\end{array}$ & $\begin{array}{l}\text { Main Effect * } \\
\text { Non-South } \\
(2)\end{array}$ & $\begin{array}{l}\text { Main Effect } \\
\text { (3) }\end{array}$ & $\begin{array}{l}\text { Main Effect * } \\
\text { Non-South } \\
(4) \\
\end{array}$ \\
\hline \multicolumn{5}{|c|}{ Pre-Dismissal } \\
\hline pre(-4) & $\begin{array}{l}-0.002 \\
(0.003)\end{array}$ & $\begin{array}{c}0.007 \\
(0.011)\end{array}$ & $\begin{array}{c}0.001 \\
(0.002)\end{array}$ & $\begin{array}{c}0.000 \\
(0.003)\end{array}$ \\
\hline pre(-3) & $\begin{array}{l}-0.002 \\
(0.006)\end{array}$ & $\begin{array}{c}0.006 \\
(0.022)\end{array}$ & $\begin{array}{l}-0.002 \\
(0.003)\end{array}$ & $\begin{array}{c}0.000 \\
(0.006)\end{array}$ \\
\hline pre(-2) & $\begin{array}{l}-0.003 \\
(0.008)\end{array}$ & $\begin{array}{c}0.008 \\
(0.026)\end{array}$ & $\begin{array}{c}-0.004 \\
(0.005)\end{array}$ & $\begin{array}{c}0.002 \\
(0.009)\end{array}$ \\
\hline pre(-1) & $\begin{array}{c}0.002 \\
(0.011)\end{array}$ & $\begin{array}{c}0.011 \\
(0.029)\end{array}$ & $\begin{array}{c}-0.008 \\
(0.007)\end{array}$ & $\begin{array}{c}0.005 \\
(0.011)\end{array}$ \\
\hline \multicolumn{5}{|c|}{ Post-Dismissal } \\
\hline $\operatorname{post}(0)$ & $\begin{array}{c}0.003 \\
(0.012)\end{array}$ & $\begin{array}{c}0.015 \\
(0.035)\end{array}$ & $\begin{array}{l}-0.010 \\
(0.009)\end{array}$ & $\begin{array}{c}0.005 \\
(0.013)\end{array}$ \\
\hline post(1) & $\begin{array}{c}0.023 \\
(0.014)\end{array}$ & $\begin{array}{c}0.006 \\
(0.036)\end{array}$ & $\begin{array}{l}-0.019 \\
(0.010)\end{array}$ & $\begin{array}{c}0.010 \\
(0.014)\end{array}$ \\
\hline post(2) & $\begin{array}{c}0.037 \\
(0.020)\end{array}$ & $\begin{array}{c}0.007 \\
(0.040)\end{array}$ & $\begin{array}{l}-0.020 \\
(0.011)\end{array}$ & $\begin{array}{c}0.008 \\
(0.016)\end{array}$ \\
\hline post(3) & $\begin{array}{c}0.051 \\
(0.022)\end{array}$ & $\begin{array}{l}-0.002 \\
(0.040)\end{array}$ & $\begin{array}{l}-0.025 \\
(0.013)\end{array}$ & $\begin{array}{c}0.011 \\
(0.018)\end{array}$ \\
\hline post(4) & $\begin{array}{c}0.061 \\
(0.026)\end{array}$ & $\begin{array}{l}-0.001 \\
(0.043)\end{array}$ & $\begin{array}{l}-0.028 \\
(0.015)\end{array}$ & $\begin{array}{c}0.012 \\
(0.020)\end{array}$ \\
\hline post(5) & $\begin{array}{c}0.062 \\
(0.026)\end{array}$ & $\begin{array}{c}0.002 \\
(0.044)\end{array}$ & $\begin{array}{c}-0.031 \\
(0.017)\end{array}$ & $\begin{array}{c}0.012 \\
(0.022)\end{array}$ \\
\hline post(6) & $\begin{array}{c}0.076 \\
(0.028)\end{array}$ & $\begin{array}{c}-0.002 \\
(0.045)\end{array}$ & $\begin{array}{l}-0.042 \\
(0.018)\end{array}$ & $\begin{array}{c}0.022 \\
(0.025)\end{array}$ \\
\hline $\begin{array}{l}\text { Number of Observations } \\
\text { Dep. Var. Mean } \\
\text { Dep. Var. S.D. } \\
\text { Dep Var. } 1991 \text { Cross Section S.D.* }\end{array}$ & & & & \\
\hline
\end{tabular}

Note. Standard errors, clustered by district, are presented in parentheses. The sample is restricted to those districts under courtorder in 1991. Column (1) and (2) display the results of a single regression. Columns (3) and (4) display the results of a single regression. Columns (1) and (3) display the main effect coefficients. Columns (2) and (4) display the main effect interacted with an indicator for being outside the south census region coefficients. The specification, similar to column (2) on tables 2 and 4 , includes a district fixed effect, vector of year, census regions interactions and a vector of base period demographic characteristics interacted with year indicators. Base period demographic characteristics include a central city indicator variable, number of students enrolled, number of students enrolled squared, percent of students who are white and percent of students who are hispanic. 